Article

\title{
Assimilation of Snowmelt Runoff Model (SRM) Using Satellite Remote Sensing Data in Budhi Gandaki River Basin, Nepal
}

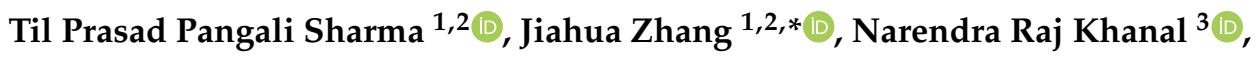 \\ Foyez Ahmed Prodhan 1,2,4 (D), Basanta Paudel ${ }^{5}$ (D), Lamei Shi ${ }^{1,2}$ and Nirdesh Nepal ${ }^{2,6}$ (D) \\ 1 Key Laboratory of Digital Earth Sciences, Aerospace Information Research Institute (AIR), Chinese Academy \\ of Sciences (CAS), Beijing 100094, China; tilsharma@radi.ac.cn (T.P.P.S.); foyez@bsmrau.edu.bd (F.A.P.); \\ shilm@radi.ac.cn (L.S.) \\ 2 University of Chinese Academy of Sciences, Beijing 100049, China; nepaln@imde.ac.cn \\ 3 Central Department of Geography, Tribhuvan University, Kathmandu 66613, Nepal; \\ nrkhanal.geog@gmail.com \\ 4 Bangabandhu Sheikh Mujibur Rahman Agricultural University, Gazipur-1706, Bangladesh \\ 5 Key Laboratory of Land Surface Pattern and Simulation, Institute of Geographic Sciences and Natural \\ Resources Research, Chinese Academy of Sciences, Beijing 100101, China; paudelb@igsnrr.ac.cn \\ 6 Key Laboratory of Mountain Hazards and Land Surface Processes, Institute of Mountain Hazards and \\ Environment, Chinese Academy Sciences (CAS), Chengdu 610041, China \\ * Correspondence: zhangjh@radi.ac.cn; Tel.: +86-10-82178122
}

Received: 3 May 2020; Accepted: 12 June 2020; Published: 17 June 2020

check for updates

\begin{abstract}
The Himalayan region, a major source of fresh water, is recognized as a water tower of the world. Many perennial rivers originate from Nepal Himalaya, located in the central part of the Himalayan region. Snowmelt water is essential freshwater for living, whereas it poses flood disaster potential, which is a major challenge for sustainable development. Climate change also largely affects snowmelt hydrology. Therefore, river discharge measurement requires crucial attention in the face of climate change, particularly in the Himalayan region. The snowmelt runoff model (SRM) is a frequently used method to measure river discharge in snow-fed mountain river basins. This study attempts to investigate snowmelt contribution in the overall discharge of the Budhi Gandaki River Basin (BGRB) using satellite remote sensing data products through the application of the SRM model. The model outputs were validated based on station measured river discharge data. The results show that SRM performed well in the study basin with a coefficient of determination $\left(\mathrm{R}^{2}\right)>0.880$. Moreover, this study found that the moderate resolution imaging spectroradiometer (MODIS) snow cover data and European Centre for Medium-Range Weather Forecasts (ECMWF) meteorological datasets are highly applicable to the SRM in the Himalayan region. The study also shows that snow days have slightly decreased in the last three years, hence snowmelt contribution in overall discharge has decreased slightly in the study area. Finally, this study concludes that MOD10A2 and ECMWF precipitation and two-meter temperature products are highly applicable to measure snowmelt and associated discharge through SRM in the BGRB. Moreover, it also helps with proper freshwater planning, efficient use of winter water flow, and mitigating and preventive measures for the flood disaster.
\end{abstract}

Keywords: snowmelt runoff; SRM; MODIS; ECMWF; Gandaki River 


\section{Introduction}

Discharge measurement is important for water and riverine flood management [1,2]. Snow and glacier melt shares crucial amount in perennial river discharge [3]. The flood disaster researches show that the floods in snow-fed rivers are often associated with snowmelt [1,4]. Global warming has increased snowmelt runoff, thus posing challenges to flood disaster and freshwater management [5] and ultimately to sustainable development [6]. Excess snowmelt associated with monsoon precipitation will result frequent floods in the Himalayas [1]. Hence, the assessment of water volume released from the snow and glaciers is imperative for water resources management, including flood forecasting and reservoir operation.

The Himalayan glaciers are a major source of freshwater, not directly affected by human activities; however, researchers have shown that the snow cover area is depleting due to human-induced climate change $[7,8]$. In other words, climate change is posing a severe consequence on snow and glaciers, and the snow accumulation has reduced [9]. Studies reveal that, if the global warming persists, the Himalayan glaciers melt rate will be high in the near future, and summer streamflow will be high in the Himalayas $[1,10]$. Large quantities of runoff are derived from Himalayan headwaters in the form of snowmelt and rainfall, which flows to Ganges River. Siderius et al. [11] found that snowmelt contributes $1-5 \%$ of the total annual flow of the Ganges river basin. However, there are large spatial variations in snowmelt rate over the Himalayas due to fluctuations in surface temperature and accumulated snow amount [9].

Studies show that glaciated area has been decreasing globally where the Himalaya region is not an exception [5]; about $50 \mathrm{~cm}$ to $90 \mathrm{~cm}$ yearly glacier recession has been observed in the Nepal Himalaya [12]. Regional climate projections of IPCC (2018), indicates that Central Asia will warm by $3.7^{\circ} \mathrm{C}$ by the end of the 21st century, with the largest warming over higher altitudes, particularly the Tibetan Plateau and the Himalayas [5]. The Hindu Kush Himalayas (HKH), which is a water tower for over $25 \%$ of the world population, is experiencing global warming effects [13]. The short snow season due to warm temperature decreases runoff and shifts peak river flow from summer to spring [14].

Climate change has a direct impact on snowmelt and associated streamflow results on freshwater supply, irrigation, and hydropower potential [15]. Water provision, mainly obtained from snowmelt, is a major management challenge for achieving UN Sustainable Development Goals [6], where remote sensing data and Geographic Information System (GIS) technology can play a crucial role to assess water resource and meet Sustainable Development Goals [16]. The SRM has frequently been used to measure and forecast snowmelt and associated discharge that help to water management and reduce disaster loss caused by rapid snow and glacier melt $[1,11]$. Current climate change causes an increase in glacier melt, especially during the summer monsoon season in the whole Himalayan region [1], including Nepal Himalaya.

Small-scale hydrological assessment is essential to understand the impact of climate change on hydrology and the river discharge [14]. To assess climate change impact on water resources and to evaluate streamflow variability, validation of the hydrological model in the particular basin is important. The assessment of hydrological impacts due to climate change is particularly challenging in mountain environments due to poor accessibility, sparse hydro-meteorological stations, and high altitude variations; these are also the major challenges of using a hydrological model in the Himalayan region $[9,17]$. Besides mountain environment has sensitive hydrological systems due to extreme heterogeneity in vegetation, soils, topography, and spatially and temporally varying snow cover [15]. Many studies have used satellite snow cover data and interpolated meteorological station data to run the model $[18,19]$. Although there are spare meteorological stations in the HKH region, the continuous and spatially well-distributed data is not available throughout the region.

The snowmelt runoff model (SRM) is a degree-day model developed to simulate and predict daily discharge of the glaciated mountain basin [20]. The model has been used in many studies to evaluate the climate effect on river discharge in the mountain watersheds $[10,17,21,22]$. The SRM was successfully used to assess the impact of climate change on water availability in the Upper Rio Grande 
Basin [22]. Tekeli et al. [21] used SRM using moderate resolution imaging spectroradiometer (MODIS) snow cover data to measure river discharge in a mountain watershed of Turkey [21]. Similar studies were done in the Karakoram range, northern Pakistan, where climate change impact on discharge was calculated using MODIS snow cover data in the Hunza River Basin [10]. SRM parameter uncertainty was evaluated and future snowmelt runoff was projected under various climate projections in the data-scarce deglaciating river basin of western China [23]. Besides that, Panday et al. [17] used the Markov Chain Monte Carlo (MCMC) data assimilation approach for SRM parameter estimation in the Tamor River Basin of the Himalayan region [17]. In addition to that, the SRM model was used to estimate present and future river discharge in the Karakoram Himalayan region using MODIS snow products, where annual discharge is projected to increase [1]. The SRM model at the sub-basin scale is considered beneficial to understand hydrological characteristics of the basin, which ultimately helps in freshwater management [24]. Many studies have measured snowmelt in the Himalayan region using different models [15,25,26], some of which have used SRM in the region [1,10,17]. The satellite meteorological data product is useful in hydrological modelling [27,28]. A few attempts have been made to estimate the contribution of snowmelt in river discharge using SRM in the HKH region at different scale; however, such work, particularly in the headwater of Gandaki River Basin, does not exists. This paper attempts to fulfill this research gap. The main objective of this work is to estimate snowmelt contribution in river discharge using SRM in the upper part of the Gandaki River Basin in Nepal (Figure 1) and validate European Centre for Medium-Range Weather Forecasts (ECMWF) meteorological data to run SRM in the HKH region.

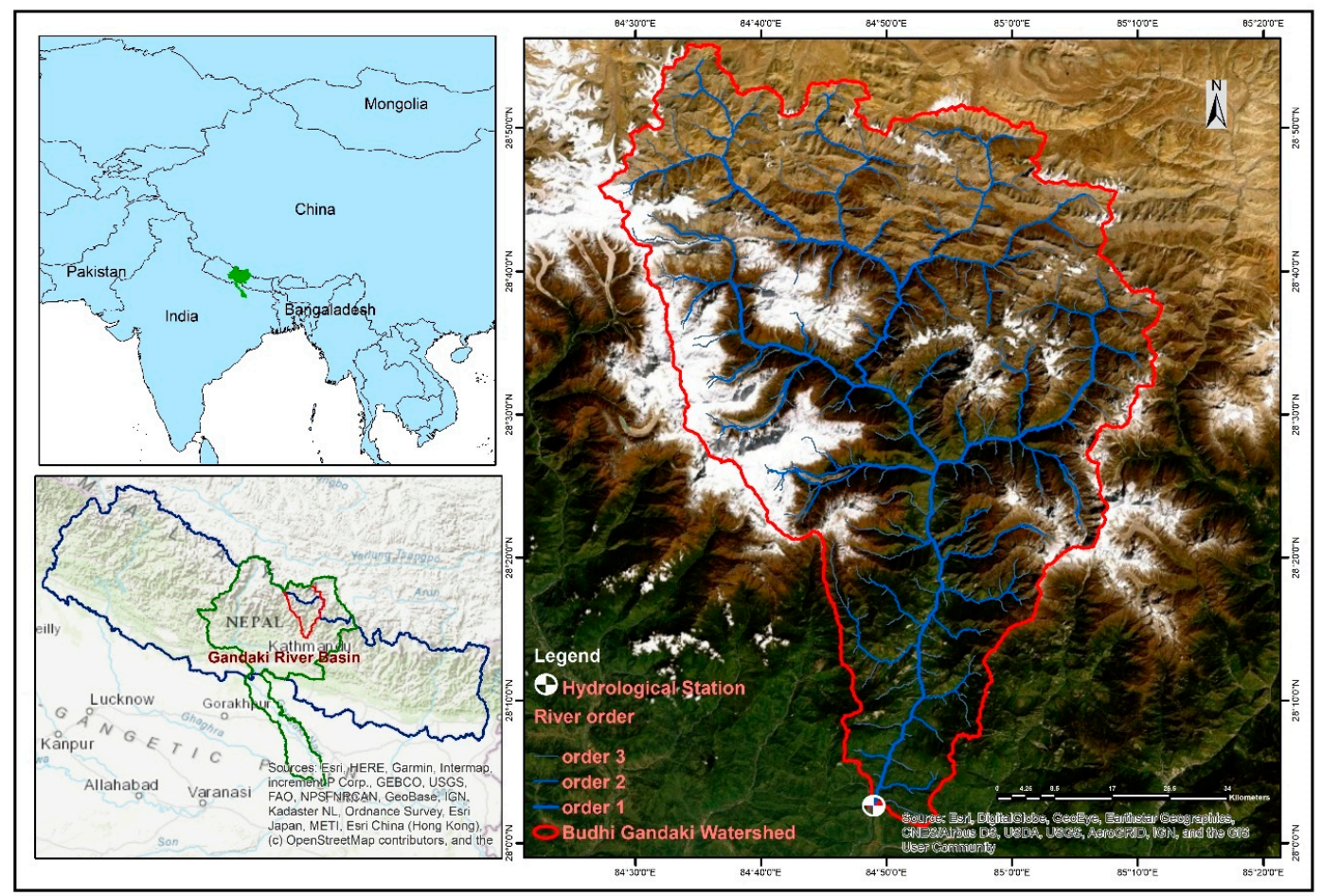

Figure 1. The topographic and administrative status of the study area.

\section{Materials and Methods}

\subsection{The Study Setting}

Major rivers such as the Indus, Ganges, Brahmaputra, Yangtze, and Yellow Rivers, originate from the HKH region [29]. The Ganges River Basin is third-largest glaciated area (1.1\%), following by Brahmaputra (3.1\%) and Indus (2.2\%), in the HKH region, whereas the Ganges River Basin has high annual precipitation as compared to other basins [29]. The total inhabitants are comparatively higher in 
the Ganges River Basin $(477,937,000)$ than Brahmaputra and Indus River Basins, where many of them rely on agriculture [29]. This situation indicates that more people will be affected by climate factors in the Ganges River Basin than in other basins. Nepal has three major river systems-Koshi, Gandaki, and Karnali-and these are all tributaries of Ganges River. The Gandaki River has seven sub-tributaries including Daraudi, Seti Gandaki, Madi, Kali Gandaki, Marsyandi, Budhi Gandaki, and Trishuli; thus, it is also called the Sapta Gandaki River System [30], and all originate from Himalayan region.

The Himalayan region has a tundra climate mostly covered by ice and glaciers, where snow line elevations are lower in the west than in the east [31]. The snow cover extent in Nepal Himalaya is high during late winter and spring, while it is least during summer monsoon season [31]. Moreover, many studies report that the temperature rise in Nepal $\left(0.6{ }^{\circ} \mathrm{C}\right.$ per decade $)$ is less than the global average $\left(0.74{ }^{\circ} \mathrm{C}\right)[32,33]$, and the past 15 years status shows that it rose by $0.0539{ }^{\circ} \mathrm{C} /$ year between 2000 and 2015 [34]. Nepal Himalaya contains 3252 glaciers and 2315 glacier lakes of various sizes and a large snow cover area $\left(2030.15 \mathrm{~km}^{2}\right)$ found in the GRB with estimated ice reserves $\left(191.39 \mathrm{~km}^{3}\right)$ which is higher than Koshi and Karnali River Basins [32]. Hence, the snowmelt associated river discharge measurement in Nepalese rivers is very important to assess the effect of climate change in the Himalayan region [29].

The Budhi Gandaki River Basin (BGRB) is located in central Nepal and is the tributary of the Gandaki River Basin originating from the Himalayas in the north (Figure 1), covering an area of 3881.16 square kilometers. The majority of BGRB lies in Gorkha district of Nepal, where the altitude varies from $479 \mathrm{~m}$ above sea level (masl) at the Arughat hydrological station to 8163 masl (Mount Manaslu) at the top of the basin. Since the basin has high altitude variation, the temperature varies along with elevation zones (Figure 2). The mean annual precipitation in the BGRB is $1800 \mathrm{~mm}$ with extremely high spatial variability within BGRB [35]. The permanent snow line is reckoned above 5000 masl in Nepal Himalaya, where precipitation occurs in the form of rain and snow. Karki et al. [36] show that there are three types of climatic condition found in the study area:- temperate climate with dry winter and warm summer, polar tundra, and polar frost. The lower part of the basin has a temperate climate with dry winters, and warm summers are found mainly in zone A and B, followed by polar tundra climate in zone $\mathrm{C}$ and $\mathrm{D}$. In addition, polar frost is found in zone $\mathrm{E}$.

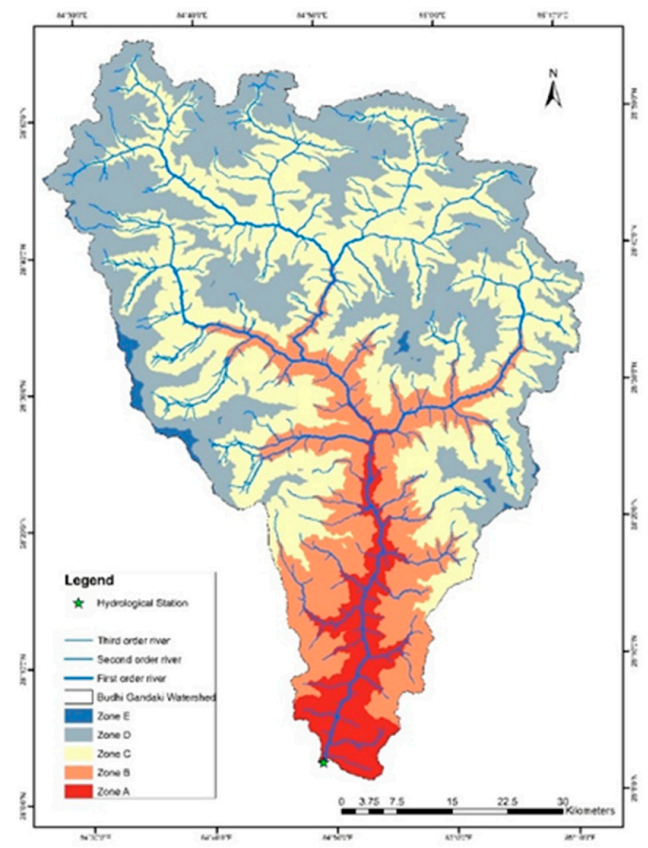

(a)

$\begin{array}{lccc}\text { Zones } & \begin{array}{c}\text { Elevation } \\ \text { range } \\ \text { (meters) }\end{array} & \begin{array}{c}\text { Mean } \\ \text { elevation } \\ \text { (meters) }\end{array} & \begin{array}{c}\text { Area in } \\ \text { square } \\ \mathbf{( k m}^{2} \text { ) }\end{array} \\ \text { Zone A } & 479-2000 & 1239.50 & 265.77 \\ \text { Zone B } & 2000-3500 & 2750.00 & 658.97 \\ \text { Zone C } & 3500-5000 & 4250.00 & 1688.95 \\ \text { Zone D } & 5000-6500 & 5750.00 & 1236.37 \\ \text { Zone E } & 6500-8147 & 7323.50 & 31.09 \\ \text { Total area } & - & - & \mathbf{3 8 8 1 . 1 6}\end{array}$

(b)

Hypsometry Curve: Budhi Gandaki River Basin

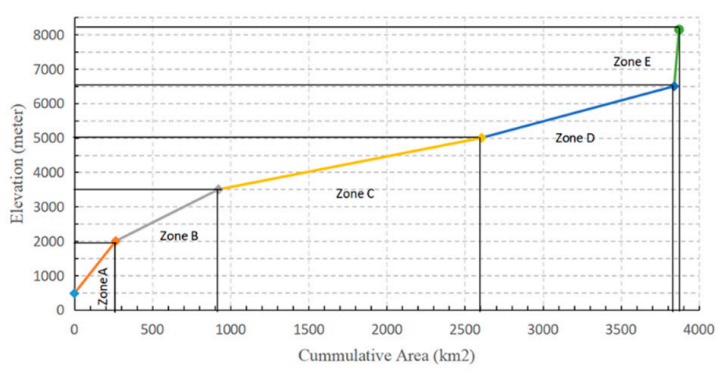

(c)

Figure 2. Zonal divisions of the basin. (a) Spatial division of the zones; (b) elevation range, mean elevation, and areas; (c) the hypsometry curve of the study area. 


\subsection{Satellite Data Used}

This study uses SRTM DEM data for topographical analysis of the basin. The MODIS snow cover data products (MOD10A2) have been used for daily snow cover, and ECMWF data is used for the precipitation and temperature data. The details of these satellite data are given below.

\subsubsection{MODIS}

The moderate resolution imaging spectroradiometer (MODIS) capture data in 36 spectral bands ranging from $0.2 \mu \mathrm{m}$ to $14.4 \mu \mathrm{m}$ at varying spatial resolutions [37]. MODIS data is open access, and moderate resolution has frequently been used for snow cover data input for SRM [1,17,18]. A study has compared NOAA-AVHRR and MODIS snow cover data to run the SRM model and found MODIS snow cover accuracy is much better than that of AVHRR data and recommended to use the MODIS data to run the model [21]. The MOD10A2 snow cover products (C6) use MODIS bands 4 and 6 to compute the NDSI snow mapping algorithm to detect snow cover pixels from the cloud-like atmospheric blockage [38]. According to Hall et al. [38], a pixel is mapped as snow if the NDSI value is less than or 0.4 and MODIS band 2 is higher than 11\%. In addition to that, the fractional snow cover (FSC) equation was applied in those pixels where snow pixel is detected from NDSI in order to get high accuracy [39].

The MOD10A2 snow cover product uses MODIS Terra surface reflectance daily data (MOD09GA), which provides 16-bit signed integer daily surface reflectance at a 500-m spatial resolution [40]. The MOD10A2 algorithm composites eight days of MOD10A1 tiles to get the snow cover extent. If the snow was found on any day during the eight days, the cell is categorized as snow in the final MOD10A2 product. On the other hand, if five days are snow free, and the last three days are cloud, the cell is defined as a snow-free pixel [38]. MOD10A2 tile covers approximately $1200 \times 1200 \mathrm{~km}\left(10^{\circ} \times 10^{\circ}\right)$ area on the Sinusoidal projection [38]. This study uses a MODIS tile (h25v06) to get snow cover area over 14 years (2005-2018). The eight-day snow cover data was downloaded from the National Snow and Ice Data platform (https://nsidc.org/data/mod10a2) for the scene h25v06 over 14 years (2005-2018).

\subsubsection{ECMWF}

Due to the inaccessible geographic location, meteorological stations are scarce in the Himalayan region. Since there are scarce meteorological stations and a lack of continuous data in Nepal, ECMWF data was selected for temperature and precipitation variables as inputs for the model. ECMWF provides a veriaty of climatic data products that are frequently used for climatic studies [41,42]. The ECMWF data provides global coverage climatic data with acceptable accuracy [43]. Many studies have used ECMWF data products in climate studies $[35,44]$. Global climate data are available in coarse spatial resolution, whereas ECMWF forecast climate data is a relatively high spatial resolution compared to other freely available climatic data. Although ECMWF data have successfully been used in many sectors $[28,44]$, this study applies a novel approach to using ECMWF temperature and precipitation data to simulate the SRM model in the Nepal Himalaya. This study measures river discharge using the SRM degree day model using remote sensing data (MODIS, ECMWF).

ECMWF routinely processes data from around 90 satellite data products as part of its operational daily data assimilation and monitoring activities. Besides that, ECMWF benefits from all available observations from non-satellite sources, including surface-based and aircraft reports (https://www. ecmwf.int/en/research/data-assimilation/observations). ERA-Interim Daily datasets for this study were accessed (https://apps.ecmwf.int/datasets/data/interim-full-daily/levtype=sfc/) and downloaded from 2005 to 2018 . The data grid $\left(0.125^{\circ} \times 0.125^{\circ}\right)$ was selected while downloading temperature and precipitation datasets in NetCDF file format using custom latitude and longitude values for the study area. 


\subsubsection{SRTM DEM}

Shuttle Radar Topography Mission (SRTM) is a near-global digital elevation model (DEM), generates the complete high resolution digital topographic datasets, using C-band SAR data [45]. Compared to other freely available DEM data, SRTM is the best DEM ever generated at the global scale with consistency and overall accuracy [46]. SRTM DEM has been used in military, civil, and scientific user communities. Besides that, it has been used in runoff modelling, flood control, soil conservations, reforestation, volcano monitoring, earthquake research, and glacier movement [47,48]. Two SRTM tiles (N28 E084, and N28 E085) of 30-m global data were downloaded using www.earthexplorer.usgs.gov, and then the watershed under study is extracted for further topographic analysis.

\subsection{Station Data}

The study area lacks continuous meteorological data for the study period, so station data were only used to validate the satellite data and analyze the accuracy of the model applied. However, we have used daily river discharge data of Arughat hydrological station (lat. 28.02.37; long. 84.48.59), which is important to validate the model output. The hydrological station data were collected for model calibration (2005/2006) and validation (2007-2012).

\subsection{Data Preparation}

After downloading satellite image data, the projection system is converted into a common projection system (WGS_1984_UTM_Zone44) for further analysis. The spatial resolution of ECMWF and MODIS are relatively coarse, hence resampling technique to delineate zone wise information of the satellite data has been adopted. Since SRTM DEM data has 30-m spatial resolution, all satellite images are resampled to $30 \mathrm{~m}$ using the Nearest Neighbor resampling technique in ArcGIS 10.4.1 environment (Environmental Systems Research Institute, Redlands, CA, USA). MODIS snow cover product and SRTM DEM was downloaded in Tagged Image File (.tif) format that can be directly processed in ArcGIS for further processing, whereas daily ECMWF temperature and precipitation data were downloaded in NetCDF file format. The python code was used to extract information from .nc data structure transferred into the ASC file format. Besides this, all data preprocessing steps were done using model builder tools in the ArcGIS environment.

As per the model requirement, we divided the study area into five elevation zones using SRTM DEM, and all necessary input variables and parameters were prepared accordingly. The study area covers $3881.16 \mathrm{~km}^{2}$ with high-altitude variation; in such conditions, the model requires different zonation. Based on the SRTM-DEM, we have divided the study area into five elevation zones and presented in the hypsometric curve (Figure 2). The hypsometry curve is the primary condition of SRM model calibration. The basin is divided into five zones of $1500 \mathrm{~m}$ in each zone. Since the basin outlet point height is $479 \mathrm{~m}$ (Arughat, Gorkha), the first elevation zone A ranges from $478 \mathrm{~m}$ to $2000 \mathrm{~m}$. Likewise, subsequent zones of $1500 \mathrm{~m}$ are created. The last zone " $\mathrm{E}$ " starts from $6500 \mathrm{~m}$ to $8147 \mathrm{~m}$. Detail about the elevation zone, mean elevation point, and the total area is presented in Figure 2. The hypsometric curve shows that zone $\mathrm{E}$ has a very small area, whereas zone $\mathrm{C}$ has a large area. In other words, zone $C$ is comparatively less steep than other zones, followed by zone D.

\subsection{Snowmelt Runoff Model (SRM)}

\subsubsection{Model Structure:}

Martinec (1975) developed the SRM model to calculate daily runoff mainly based on snow cover area, precipitation, and temperature [49]. Equation (1) has been used to calculate snowmelt runoff in the study area. The model requires daily snow cover data, total daily precipitation data, and temperature data. Besides that, the runoff coefficient, degree day factor, temperature lapse rate, and recession coefficient are major parameters used in the model. The runoff amount is different in snow and rain; hence the runoff coefficient is further divided into two coefficients for snow (Cs) and rain 
(Cr). The model parameters denote the existing basin characteristics and climatic condition, derived in various ways, have discussed in Section 2.5.3.

$$
\mathrm{Q}_{\mathrm{n}+1}=\mathrm{c}_{\mathrm{sn}} \cdot \propto_{n}\left[\left(\mathrm{~T}_{\mathrm{n}}+\Delta \mathrm{T}_{\mathrm{n}}\right) \mathrm{S}_{\mathrm{n}}+c_{r n} \mathrm{P}_{\mathrm{n}}\right] \frac{\mathrm{A} \cdot 0.01}{86400}\left(1-\mathrm{k}_{\mathrm{n}+1}\right)+\mathrm{Q}_{\mathrm{n}} \mathrm{k}_{\mathrm{n}+1}
$$

$\mathrm{Q}=$ average daily discharge; $\mathrm{Cs}=$ runoff coefficient snow; $\mathrm{Cr}=$ runoff coefficient rain; $\alpha=$ degree - day factor $\left(\mathrm{cm}^{\circ} \mathrm{C}^{-1} \cdot \mathrm{d}^{-1}\right)$ indicating the snowmelt depth resulting from 1 degree - day; $\mathrm{T}=$ number of degrees - days $\left({ }^{\circ} \mathrm{C} \cdot \mathrm{d}\right) ; \Delta \mathrm{T}=$ the adjustment by temperature lapse rate necessary because of the altitude difference between the temperature station and the average hypsometric elevation of the basin or zone; $\mathrm{S}=$ ratio of the snow-covered area to the total area; $\mathrm{P}=$ precipitation contributing to runoff $(\mathrm{cm})$. A preselected threshold temperature, TCRIT determines whether this contribution is rainfall and immediate; $\mathrm{A}=$ area of the basin or zone in square meter; $\frac{0.01}{86400}=$ conversion from $\mathrm{cm}$. $\mathrm{m}^{2} \cdot \mathrm{d}^{-1}$ to $\mathrm{m}^{3} \cdot \mathrm{s}^{-1} ; \mathrm{k}=$ recession coefficient indicating the decline of discharge in a period without snowmelt or rainfall: $\mathrm{k}=\frac{\mathrm{Q}_{\mathrm{m}+1}}{\mathrm{Q}_{\mathrm{m}}}(\mathrm{m}, \mathrm{m}+1)$ are the sequence of days during a true recession flow period); $\mathrm{n}=$ sequence of days during the discharge computation period. Source: [50].

\subsubsection{Input Variables}

Snow cover area-Since daily snow cover data products are not continuous, we chose eight-day snow cover (MOD10A2) products for this study. A linear interpolation method was used to derive daily snow cover data from the eight-day snow product and calculated SCA for each elevation zone.

Temperature-Satellite-based average daily temperature data was used in this study. One meteorological station is in operation in the study area, whereas the station does not have continuous daily data, so, it was not used in the model. We choose ECMWF 2-m surface temperature data as the input for the model.

Precipitation-Mainly, there are two types of precipitation found in the Himalaya region-rain and snow. The distinction between rain and snow is very important in SRM because rain contributes runoff on the same day that rain occurs, whereas snow contribution is delayed. Therefore, $\mathrm{T}_{\mathrm{CRIT}}$ must be determined carefully in each elevation zone that determines whether the precipitation is rain or snow. Also, if precipitation is determined to be snow, its delayed effect is treated differently depending on whether it falls over the snow-covered or snow-free area of the basin. The new snow that falls over the previously snow-covered area is assumed to be a part of the seasonal snowpack, and its effect is included in the normal depletion curve of the snow coverage. The new snow falling over the snow free area is considered as precipitation to be added to snowmelt, with this effect delayed until the next warm day. This precipitation is stored by SRM and then melted as soon as a sufficient number of degree days has occurred [49-51].

\subsubsection{Parameters}

The temperature lapse rate, runoff coefficient, degree-day factor, recession coefficient, critical temperature, and lag time are important parameters used in the SRM model. The initial parameters can be obtained from hydrological judgment, basin characteristic, physical laws, theoretical relations, and empirical regression analysis [52]. Besides, the final parameters should be determined by calibrating and adjusting these initial parameters until the model get the desired accuracy in the particular basin. Once the parameters are adjusted, these parameters values are used for the rest of the years. Depending on the climatic condition of the basin, parameters can be adjusted from lower elevation to upper elevation (Table 1). 
Table 1. Parameter Values Range Used for the Snowmelt Runoff Model (SRM).

\begin{tabular}{ccccccccc}
\hline $\begin{array}{c}\text { Study Area } \\
\text { (Source) }\end{array}$ & $\begin{array}{c}\text { Degree Day } \\
\left({ }^{\circ} \mathbf{C}^{-1} \cdot \mathbf{d}^{-1} \mathbf{)}\right.\end{array}$ & $\begin{array}{c}\text { Lapse Rate } \\
\left({ }^{\circ} \mathbf{C} \text { per 100 } \mathbf{~ m}\right)\end{array}$ & $\begin{array}{c}\mathbf{T}_{\mathrm{CRIT}} \\
\left({ }^{\circ} \mathbf{C}\right)\end{array}$ & $\mathbf{C r}$ & $\mathbf{C s}$ & $\begin{array}{c}\text { Lag } \\
\text { Time (h) }\end{array}$ & x-Coefficient & y-Coefficient \\
\hline WMO test all (a) & $0.03-0.76$ & $0-1.12$ & $(-2.0)-5.5$ & $0.18-1.0$ & NA & 0 to 18 & NA & NA \\
\hline WMOSRM (a) & $0.2-0.65$ & $0-0.65$ & $0.75-3.0$ & $0.18-1.0$ & NA & 6 to 18 & NA & NA \\
\hline All SRM (a) & $0.09-0.73$ & $0.59-0.95$ & $0.75-3.0$ & $0.10-1.0$ & NA & 4 to 24 & NA & NA \\
\hline Koshi Basin (b) & $0.30-0.90$ & $0.50-0.70$ & $0.00-2.0$ & $0.30-0.8$ & $0.3-0.8$ & 18 & $0.9-1.4$ & $0.0-0.25$ \\
\hline Present study & $0.30-0.90$ & $0.40-0.75$ & $0.00-2.0$ & $0.25-0.90$ & $0.25-0.95$ & 4 to 24 & $0.85-1.25$ & $0.01-0.25$ \\
\hline \multicolumn{7}{c}{ a: Martinec and Rango [51]; b: Panday et al. [17]. }
\end{tabular}

If the initial parameters are not in good agreement, Martinec (1983) suggests reviewing the accuracy of snow cover data first and reconsidering the lapse rate, runoff coefficient, degree day factor, precipitation, and recession coefficient, respectively [50]. This study derives initial parameters from the Koshi River Basin [17], which has the similar climatic condition; later, the parameters were modified based on the hydrological and physical condition of the study area until the model has the desired accuracy.

In the SRM model, degree-day factor plays a very crucial role in runoff calculation. Usually, the melt factor (degree day value) in SRM can be given as a constant from direct observation [50]. However, the literature suggests that the melt factor varies with seasons, altitude, and geographical locations [22,52]. A study found that there are large spatial-temporal variations of snowmelt rate over the Himalaya region, ranging from $0.02 \mathrm{~cm} /{ }^{\circ} \mathrm{C} /$ day to $0.6 \mathrm{~cm} /{ }^{\circ} \mathrm{C} /$ day [53]. The degree-day factor is also related to relative snow density; thus the general seasonal increase in snow density is used as an index for an increase in degree-day factor [25]. In the study area, this factor is gradually increasing from $0.35 \mathrm{~cm}^{\circ} \mathrm{C}^{-1} \cdot \mathrm{d}^{-1}$ in April to $0.65 \mathrm{~cm}^{\circ} \mathrm{C}^{-1} \cdot \mathrm{d}^{-1}$ in October in zone E (Table 1). The time lag describes the total time it takes for water to reach the outlet, which is determined directly from hydrograph record. Based on the size of the basin and previous studies, we assigned a different parameter value to different elevation zones (Table 1).

The surface air temperature is directly related to elevation [54]. The temperature lapse rate is calculated based on the temperature stations available at a different altitude and it can be estimated using a linear regression model [54]. In SRM simulation, a lapse rate of $0.65{ }^{\circ} \mathrm{C}$ per $100 \mathrm{~m}$ is most frequently used [55]. It should either determined from historical data, or appropriate value must be evaluated by analogy from other basins or with regard to climatic conditions [51]. Based on the study done in the southern Himalayas [36,54], we set initial temperature lapse rate for SRM $\left(0.45^{\circ} \mathrm{C}\right.$ in January, $0.65{ }^{\circ} \mathrm{C}$ in April, $0.85^{\circ} \mathrm{C}$ in July, and $0.75^{\circ} \mathrm{C}$ per $100 \mathrm{~m}$ in September). The studies show that the critical temperature is also varied with different climatic condition and altitude of the basin, whereas the value is generally above the $0{ }^{\circ} \mathrm{C}$ [56]. In addition to that, this is very important during the snowmelt season in order to decide whether precipitation immediately contributes to runoff [51].

The runoff coefficient deals with water losses, derived from the difference between the available water volume in the basin and outflow from the basin. At the beginning of the snowmelt season, the losses are minimal since they are limited to evaporation from the snow surface, and the c value is near 1.0, especially at high elevations [51]. Later, when soil becomes exposed and vegetation grows, more losses must be expected due to evapotranspiration and interception, and the runoff coefficient generally decreases [52]. Besides that, the larger the basin size, generally, the lower the coefficient value expected [51]. Therefore, the runoff coefficient is different for the various seasons; the initial runoff coefficient is estimated from 0.90 in April to 0.25 in July to 0.95 in September.

Analysis of historical discharge data is a good way of determining recession coefficient. SRM is very sensitive with $\mathrm{k}$ value since it is the proportion of the daily meltwater production which immediately appears in the runoff. In addition, the variability of $\mathrm{k}$ concerning the current discharge should be taken into account by determining the constants $x$, y; used in the SRM equation. Generally, if the model responds too quickly to any changes in daily input, we should change the coefficient $x, y$ 
value of the model [51]. A study found that recession coefficient ( $x$ and $y$ value) and lapse rate are the most sensitive parameters in the SRM model [17]. Therefore, these parameters should be carefully determined while calibrating the model.

The initial parameters for the study area were derived from the study done by Panday et al. [17] in the Koshi river basin of Nepal. After setting up the initial parameter, we followed Martinec's (1986) suggestion to change the initial parameter, they put forward seven probable causes that may deviate the model output [51]. Martinec [50] suggests reevaluating snow cover depletion to check the error that results in too high or too low computed runoff. Besides that, he proposed to adjust the parameter value based on basin characteristics and altitude zones [50]. In this way, the final parameters are determined for this study, which are presented in Table 1.

\subsection{Validation}

Validation of the model output is a very important component of any scientific research, and SRM streamflow accuracy assessment is no exception. There are two methods-coefficient of determination $\left(R^{2}\right)$ and the volume difference (Dv) - that have frequently been used to validate SRM outcomes [50]. This study also uses these frequently used SRM validation methods $\left(R^{2}\right.$ and $\left.D v\right)$ to check the model accuracy (Equations (2) and (3)).

$$
R^{2}=1-\frac{\sum_{i=1}^{n}\left(Q_{i}-Q_{i}^{\prime}\right)^{2}}{\sum_{i=1}^{n}\left(Q_{i}-\bar{Q}^{\prime}\right)^{2}}
$$

where $Q_{i}$ is measured daily discharge, $Q_{i}^{\prime}$ is the computed daily discharge, $\bar{Q}^{\prime}$ is the average measured discharge of the given year, and $\mathrm{n}$ is the number of daily discharge value.

$$
D_{v}(\%)=\frac{V_{R}-V_{R}^{\prime}}{V_{R}} \cdot 100
$$

where $V_{R}$ is the yearly measured or seasonal runoff volume and $V_{R}^{\prime}$ is the computed yearly or seasonal runoff volume.

\section{Results}

\subsection{Snow Cover Area}

The total snow cover area of the basin was about 77\% in January, February, and March (Figure 3). The snow cover area decreased sharply from April and reached to its lowest (about 38\%) in June, July, August, and September (Figure 3). The snow accumulation starts in October in the study area. Figure 3 shows the inverse relationship between snow cover area and temperature rise. In response to increased surface temperature, the snow cover area decreased from the beginning of March and started to increase river discharge (Figure 3).

Yearly temporal snow cover in the study basin is related to temperature, precipitation, and overall river discharge (Figure 4). The elevation minimum, average, and maximum snow cover area of the 14-year period (snow cover fraction) range from 0 (no snow) to 1 (fully covered by snow) presented in Figure 4.

To get yearly snow cover fraction (SCF) among the five elevational zones, we calculated annual fractional snow cover of the study periods (14 years). Later, we categorized the minimum, average, and maximum snow cover area in each zone of the basin, which are presented in Figure 4. High snow cover fluctuations observed in zone A particularly during the winter season, where fractional snow cover is less than 0.1. The average SCF of zone B is 0.3 in the first three months of the year, whereas it goes down to 0.1 in May and June. Since the total area of the zone $C$ is high in comparison to other zones (Figure 4), SCF of this basin matters significantly for overall snowmelt runoff. The average SCF of zone $C$ is about 0.8 in the first three months of the year, whereas it goes down to 0.4 from June to 
September. Fewer SCF fluctuations are seen in zone D and E, where average SCF is more than 0.8 throughout the year.

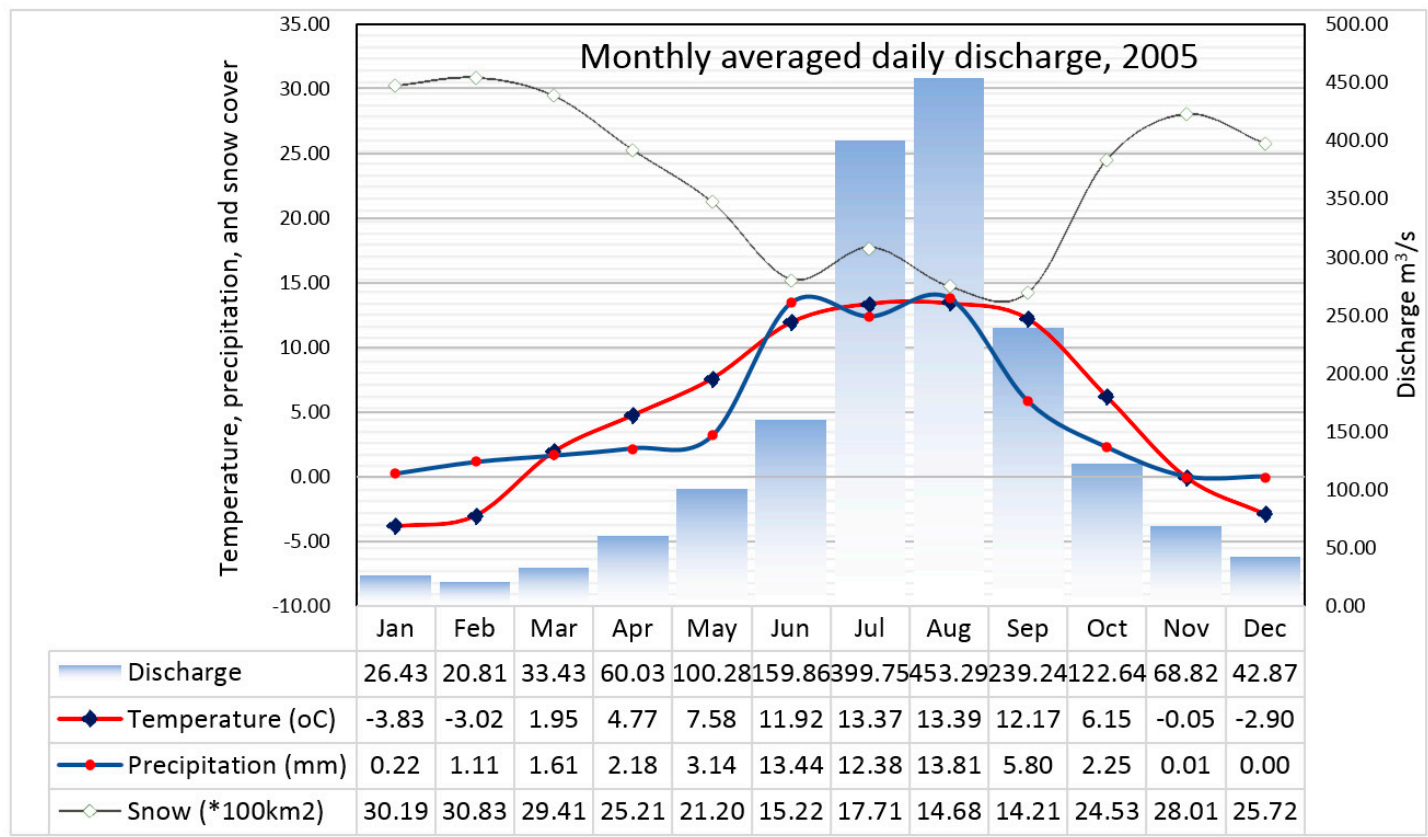

Figure 3. Comparison of monthly average river discharge at the outlet with average snow cover, temperature, precipitation in the Budhi Gandaki River Basin, 2005.

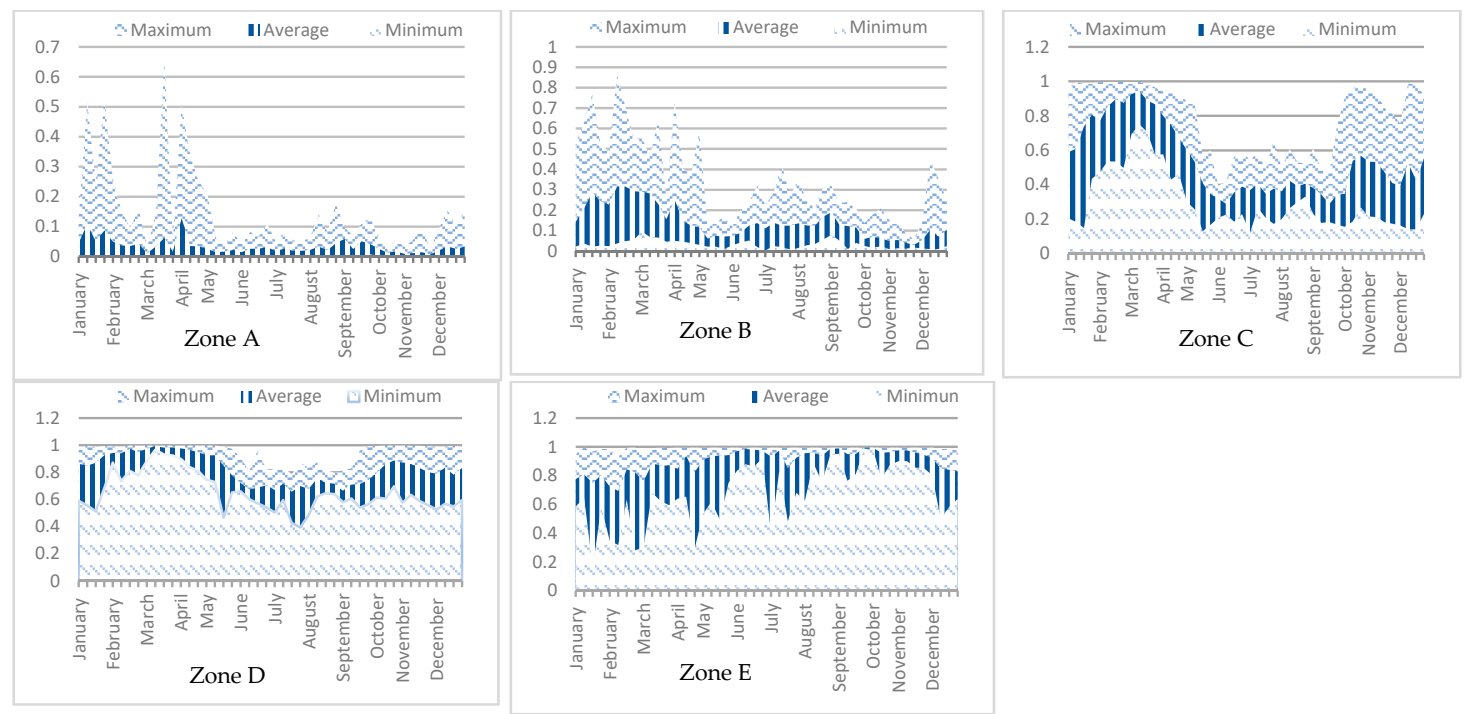

Figure 4. Snow cover fraction (SCF) variation among different zones derived from moderate resolution imaging spectroradiometer (MODIS) eight-day snow cover product MOD10A2 from the year 2005 to 2018.

The spatial distribution and temporal changes of snow cover in BGRB noted to vary between 2005 to 2018 (Figure 5). Since this study carried out a yearly simulation of SRM to see annual fluctuations of snowmelt discharge of the basin, the analysis of a number of snow days helps to determine the degree days of the respective year. Figure 5 shows some of the fluctuations of snow cover days over the period, where snow cover days were high in 2005 and reduced slowly up to 2012, and then increased again in 2013 and 2014. The last three years (2016-2018) show less snow cover days, particularly in the 
northern part of the study area (Figure 5). However, the number of snow days were high in the years 2005, 2013, and 2014.

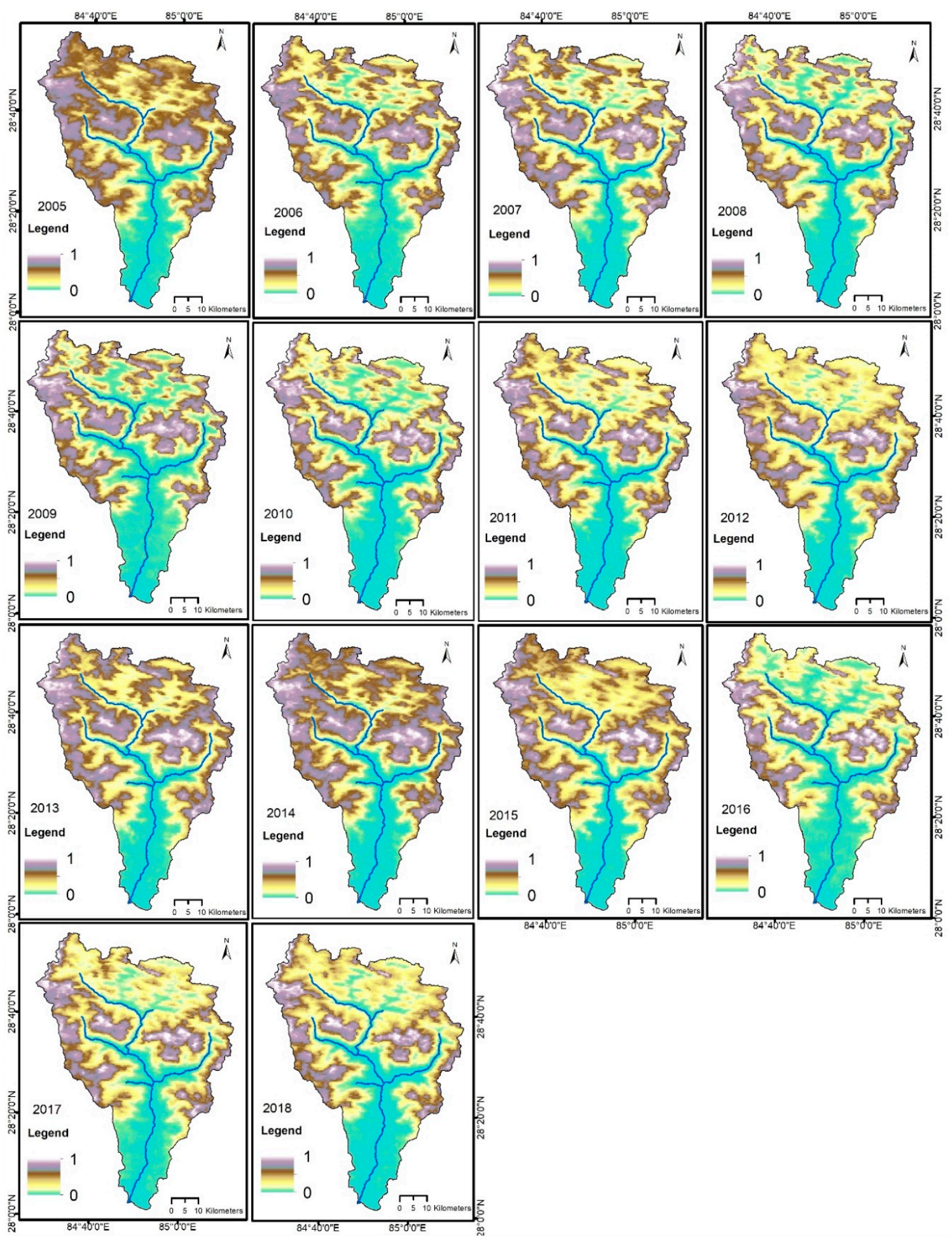

Figure 5. Spatial distribution of snow cover density from 2005 to 2018. The highest range 1 denotes the area with snow cover for 365 days, whereas the least 0 denotes the pixel without snow throughout the study years. 


\subsection{SRM Output}

\subsubsection{Assimilation Mode}

The average river discharge of the basin was calculated based on Equation (1). The average measured runoff was $147.76 \mathrm{~m}^{3} / \mathrm{s}$, while the computed SRM average runoff was $145.07 \mathrm{~m}^{3} / \mathrm{s}$ in 2005 . However, the modelled and computed average discharge was almost similar (measured $150.56 \mathrm{~m}^{3} / \mathrm{s}$ and computed $150.45 \mathrm{~m}^{3} / \mathrm{s}$ ) (Figure 6).

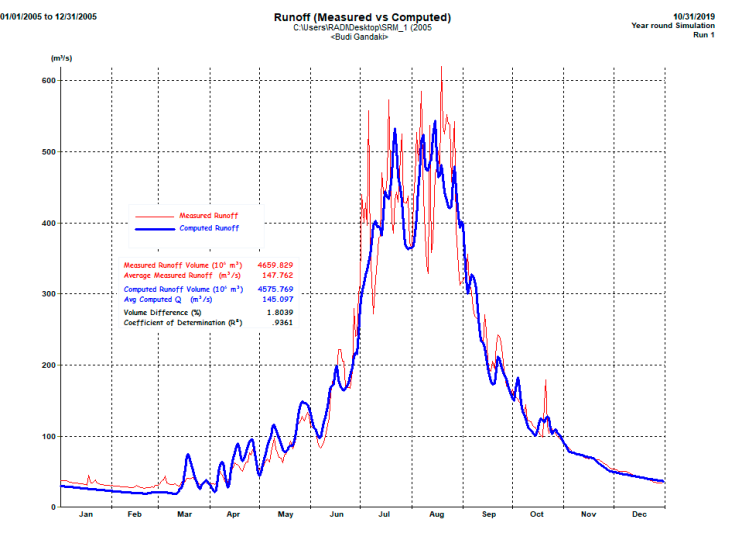

(a)

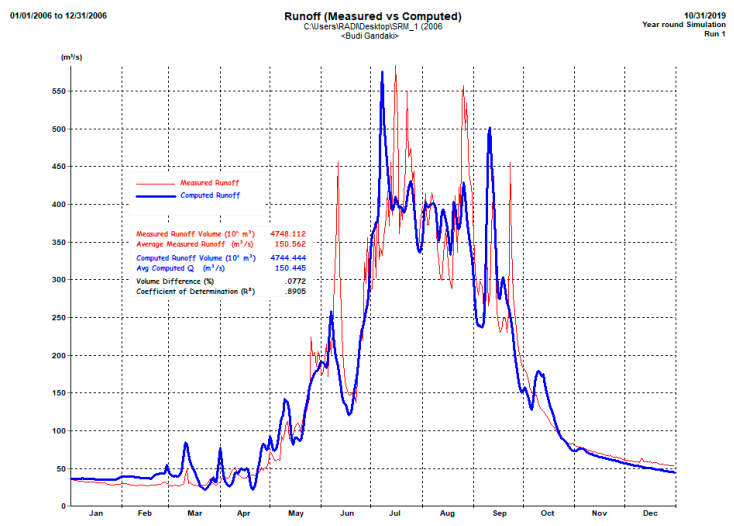

(b)

Figure 6. Simulation mode/parameter calibration for the year (a) 2005, and (b) 2006

The calibration result for the study area shows that the volume difference (\%) and the coefficient of determination $\left(\mathrm{R}^{2}\right)$ are $1.8 \%$ and 0.93 , respectively, in the year 2005 (Figure 6). Besides, a set of calibrated model parameter range for this study basin is presented in Table 1, which is used as input parameters for SRM.

\subsubsection{Forecast Mode}

Daily river discharge forecasting is one of the major advantages of using SRM model. The following Figure 7 shows SRM daily river discharge for the BGRB and compares the result with station daily river discharge records.

The capability of SRM to forecast river discharge in the Budhi Gandaki River is presented in Figure 7. The SRM forecast results are compared with station-based measurement, where SRM can detect the peak river discharge of the basin. However, SRM measurement is unable to grasp the extreme peak flow of the river (Figure 7).

The station data shows that average daily discharge is $150.23 \mathrm{~m}^{3} / \mathrm{s}$, whereas the calculated average discharge is $147.06 \mathrm{~m}^{3} / \mathrm{s}$ (Table 2). The calculated discharge was high in the years 2007, 2008, 2010, and 2011, where the hydrological station records were equally elevated in the respective years. In addition, Table 2 shows the volume difference and coefficient of determination of the computed river discharge based on the station record. Due to the lack of hydrological station data, we consider only eight years to test the model result. Volume difference (Dv) shows that the model performed well in the basin, where it shows less than 0.5 in the years 2006, 2007, 2008, and 2012 out of the eight study years. Besides that, the coefficient of determination $R^{2}$ also shows good agreement in the study basin, where $R^{2}$ is more than 0.90 throughout the study period, except in the year $2009\left(R^{2}=0.88\right)$. 

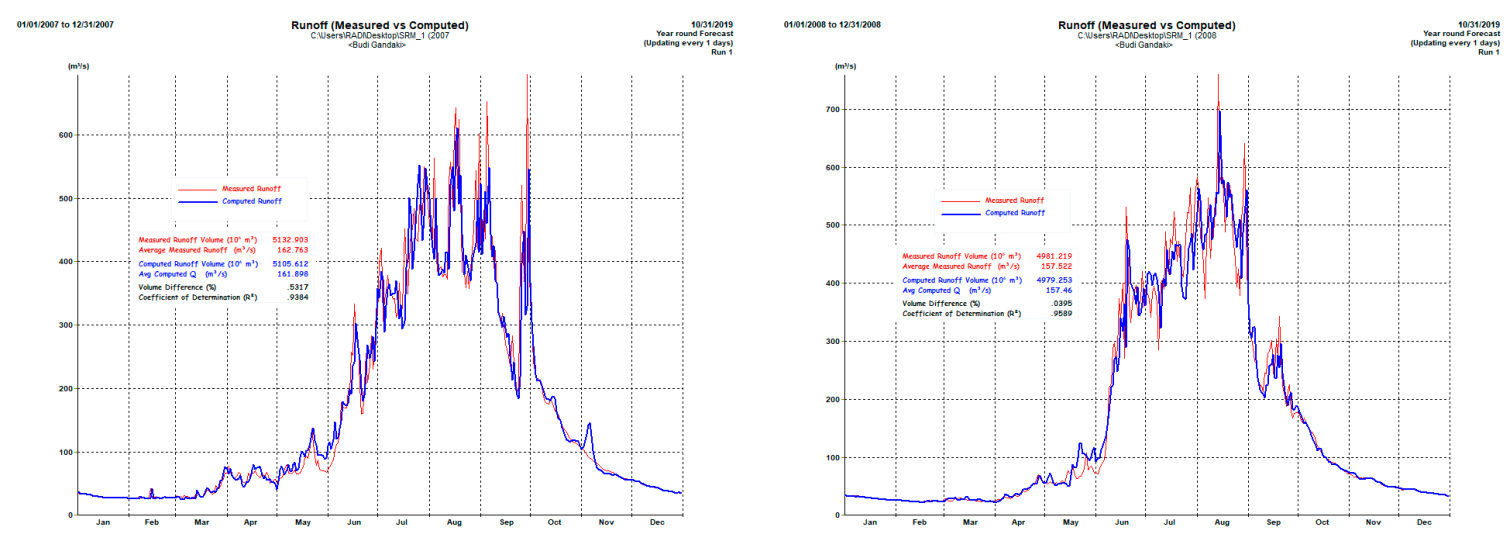

(a)

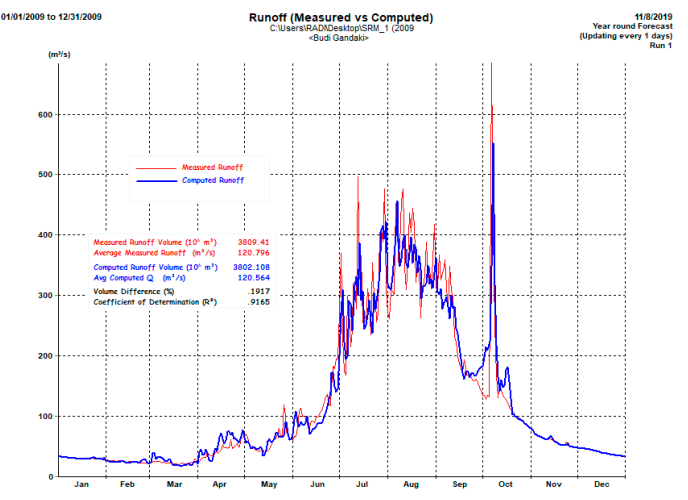

(b)

(c)

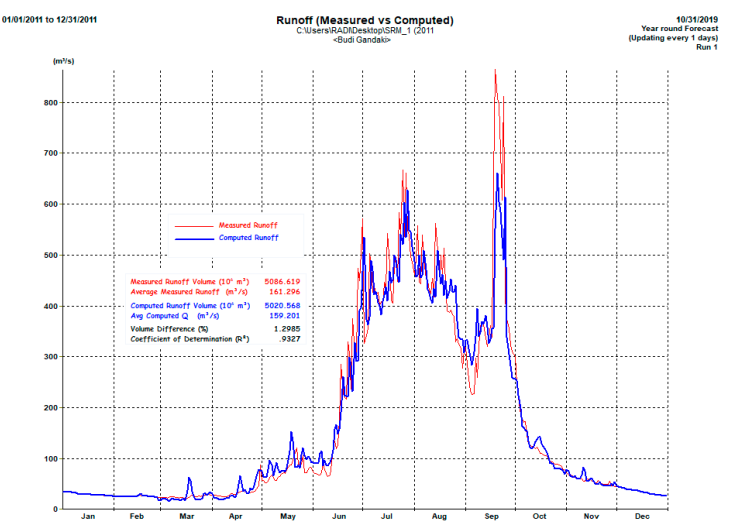

(e)

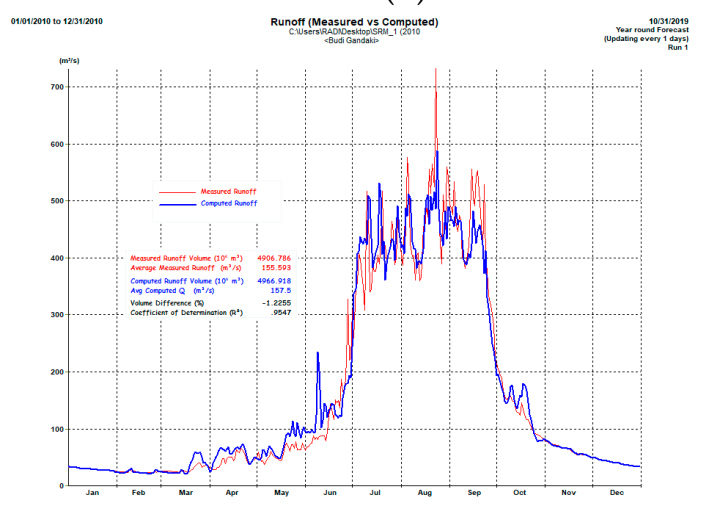

(d)

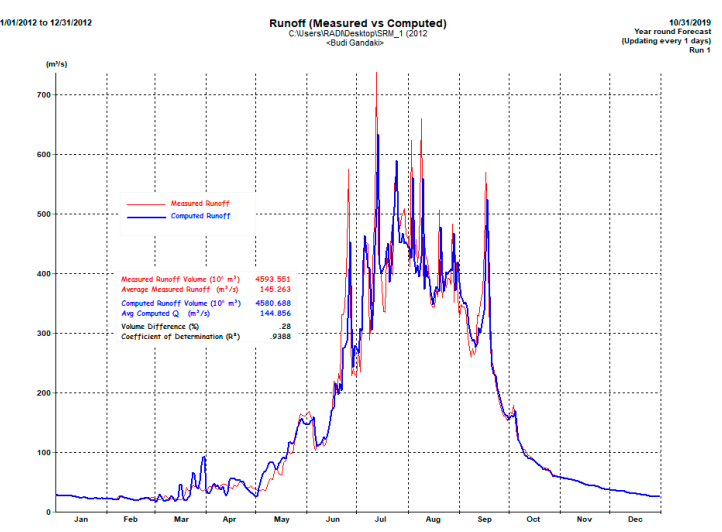

$(\mathbf{f})$

Figure 7. Measured and computed daily river discharge in SRM forecast mode; (a) 2007, (b) 2008, (c) 2009, (d) 2010, (e) 2011, (f) 2012.

The SRM output of the study basin is presented in the following Figure 8 . The yearly average of the study period is about $147.06 \mathrm{~m}^{3} / \mathrm{s}$. Although average discharge has not changed measurably, peak discharge has reduced consistently in the last few years. There was less discharge (calculated and measured) in 2009, where the peak flow was about $400 \mathrm{~m}^{3} / \mathrm{s}$ during June, July, and August, which has the highest flow in rest of the years, except the last year (2018) (Figure 8). 
Table 2. Comparison of the Model Result and Station Measured River Discharge.

\begin{tabular}{|c|c|c|c|c|c|}
\hline Year & $\begin{array}{c}\text { Station Record } \\
\left(\mathrm{m}^{3} / \mathrm{s}\right)\end{array}$ & $\begin{array}{l}\text { Model Result } \\
\left(\mathrm{m}^{3} / \mathrm{s}\right)\end{array}$ & $\begin{array}{l}\text { Computed Total Runoff } \\
\text { Volume }\left(10^{6} \mathrm{~m}^{3}\right)\end{array}$ & $\begin{array}{l}\text { Volume Difference (Dv) } \\
\text { in Percent }\end{array}$ & $\begin{array}{c}\text { Coefficient of } \\
\text { Determination }\left(R^{2}\right)\end{array}$ \\
\hline 2005 & 147.76 & 145.09 & 4575.77 & 1.80 & 0.936 \\
\hline 2006 & 150.86 & 150.45 & 4744.44 & 0.07 & 0.905 \\
\hline 2007 & 162.76 & 161.09 & 5105.61 & 0.53 & 0.938 \\
\hline 2008 & 157.52 & 157.46 & 4979.25 & 0.03 & 0.958 \\
\hline 2009 & 120.79 & 121.89 & 3846.89 & -0.98 & 0.880 \\
\hline 2010 & 155.59 & 157.50 & 4966.92 & -1.22 & 0.954 \\
\hline 2011 & 161.29 & 159.20 & 5020.56 & 1.29 & 0.932 \\
\hline 2012 & 145.26 & 144.85 & 4580.68 & 0.280 & 0.938 \\
\hline 2013 & NA & 153.96 & 4855.37 & - & \\
\hline 2014 & NA & 144.94 & 4570.69 & - & \\
\hline 2015 & NA & 133.97 & 4224.89 & - & \\
\hline 2016 & NA & 147.03 & 4649.61 & - & \\
\hline 2017 & NA & 147.01 & 4635.99 & - & \\
\hline 2018 & NA & 134.51 & 4241.78 & - & \\
\hline
\end{tabular}

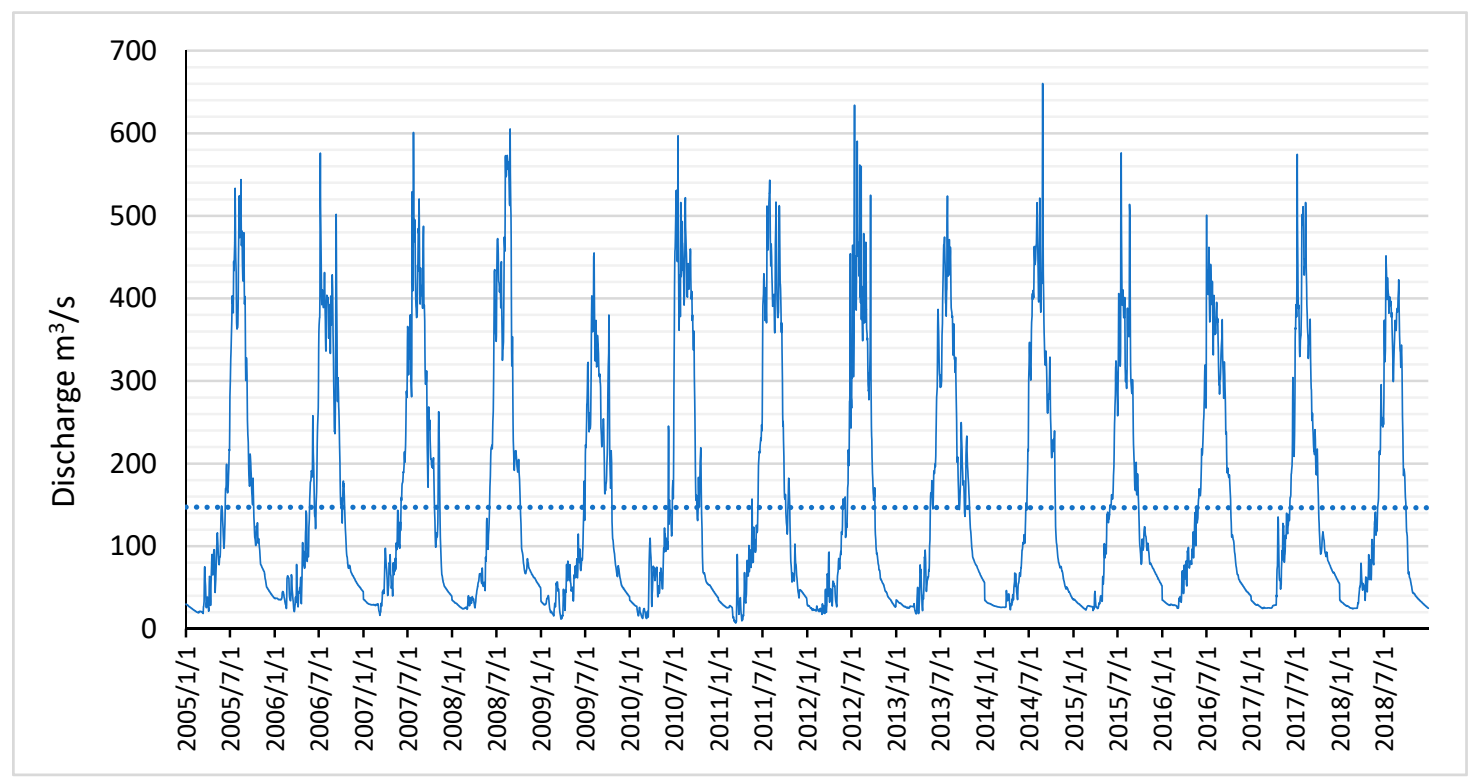

Figure 8. Daily calculated river discharge from 2005 to 2018.

\subsubsection{The Relation between Daily Temperature, Precipitation, and Snow Cover}

The river discharge looks almost constant until March. There was a slight increase in discharge with some fluctuations until mid-June. The peak discharge has observed in July and August in both station records and model output. The river discharge starts decreasing in September and onward until December, where slight downward fluctuations were observed in mid-October, and the discharge remains stable in November and onward. The snow-covered area was about $77.27 \%$ of the total basin until mid-March, and the area starts decreasing with temperature rise from the end of March.

High fluctuations in precipitation and river discharge does not correspond to the initial rainfall of the year (Figure 9). In contrast, the mode starts to respond to rainfall fluctuations from mid-March onward. It also indicates that the model can respond to rainfall-induced discharge studies that have been using SRM in mountain basin without permanent snow $[10,18]$. As expected, high rainfall fluctuations have been observed during the monsoon season (Figure 9). 


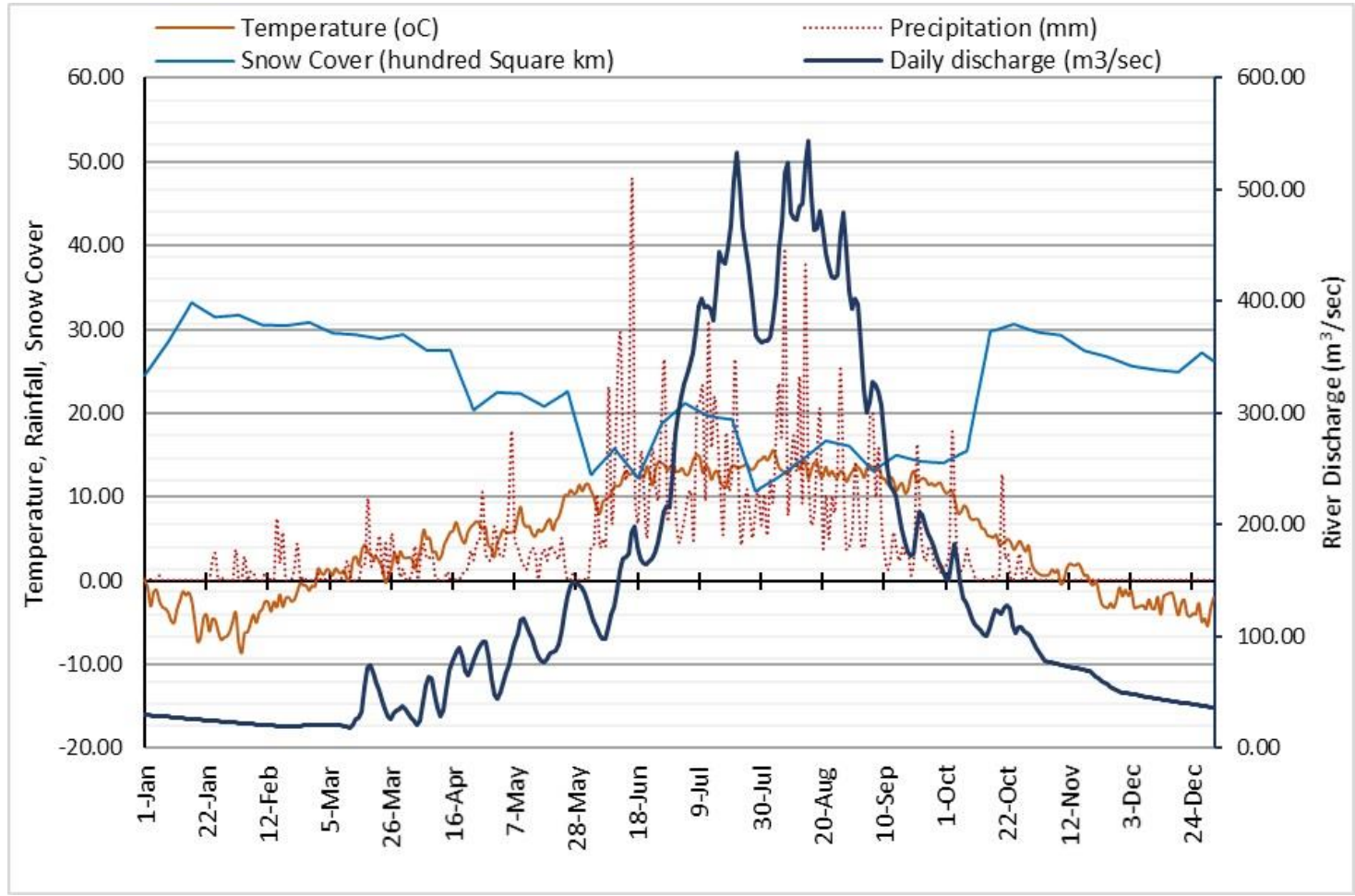

Figure 9. SRM input variables and its relation with discharge in 2005.

\section{Discussion}

\subsection{Snow Cover Area in the Basin}

Many South Asian rivers originate from the Himalayan region, and the HKH region is mainly covered by snow and ice $[57,58]$. Hence, snowmelt accounts for a significant amount of total annual river discharge [59] - more than $60 \%$ of total annual discharge accounted for snowmelt in the study area. Freshwater management and flood risk management are significant challenges to meeting UN sustainable development goals [6], particularly in the face of climate change [60]. Fitting a model for small river basins is crucial in order to use the model in flood and freshwater management [1]; hence, this study uses SRM in BGRB. The Budhi Gandaki River is also the major freshwater source mainly used for agriculture and household purposes downstream [30]. This study shows that spatial snow cover of the basin has reduced in the last few years, and depressed associated runoff is therefore observed (Figures 5 and 7).

The snow cover area is directly related to the altitude of the basin, where zones D and E hace high permanent snow cover and fewer fluctuations throughout the year. However, high snow cover inter-annual fluctuations were observed in zone $\mathrm{C}$, which is the largest zone of the study area and has significant influence on the total runoff calculation. Since snow cover plays a crucial role in discharge, the spatial and temporal pattern of snow cover observed in the study area, particularly in the north (Figure 5), is important. Observed total snow cover days was less in the last three years, which has affected the total basin runoff.

On average, more than $60 \%$ of total annual rainfall discharge is contributed by snowmelt water during the peak months of May and June. In addition, monsoon rainfall is another important source of river discharge, especially during the monsoon and post-monsoon season in the Himalayan region [9]. The high snowmelt water together with intense monsoon rainfall poses a risk of flood disaster [1]; however, no direct snowmelt-associated flood loss have been observed in the study area.

Likewise, the present study validates the snowmelt runoff model (SRM) to estimate streamflow for the Budhi Gandaki River Basin. This study indicates that snowmelt contributes to the majority 
of the river flow in the study area. However, the 14-year river discharge analysis revealed that the contribution of snowmelt runoff to total discharge has been reduced in the last few years. The depressed snowmelt is related to fewer snow days occurring in the basin (Figure 10).

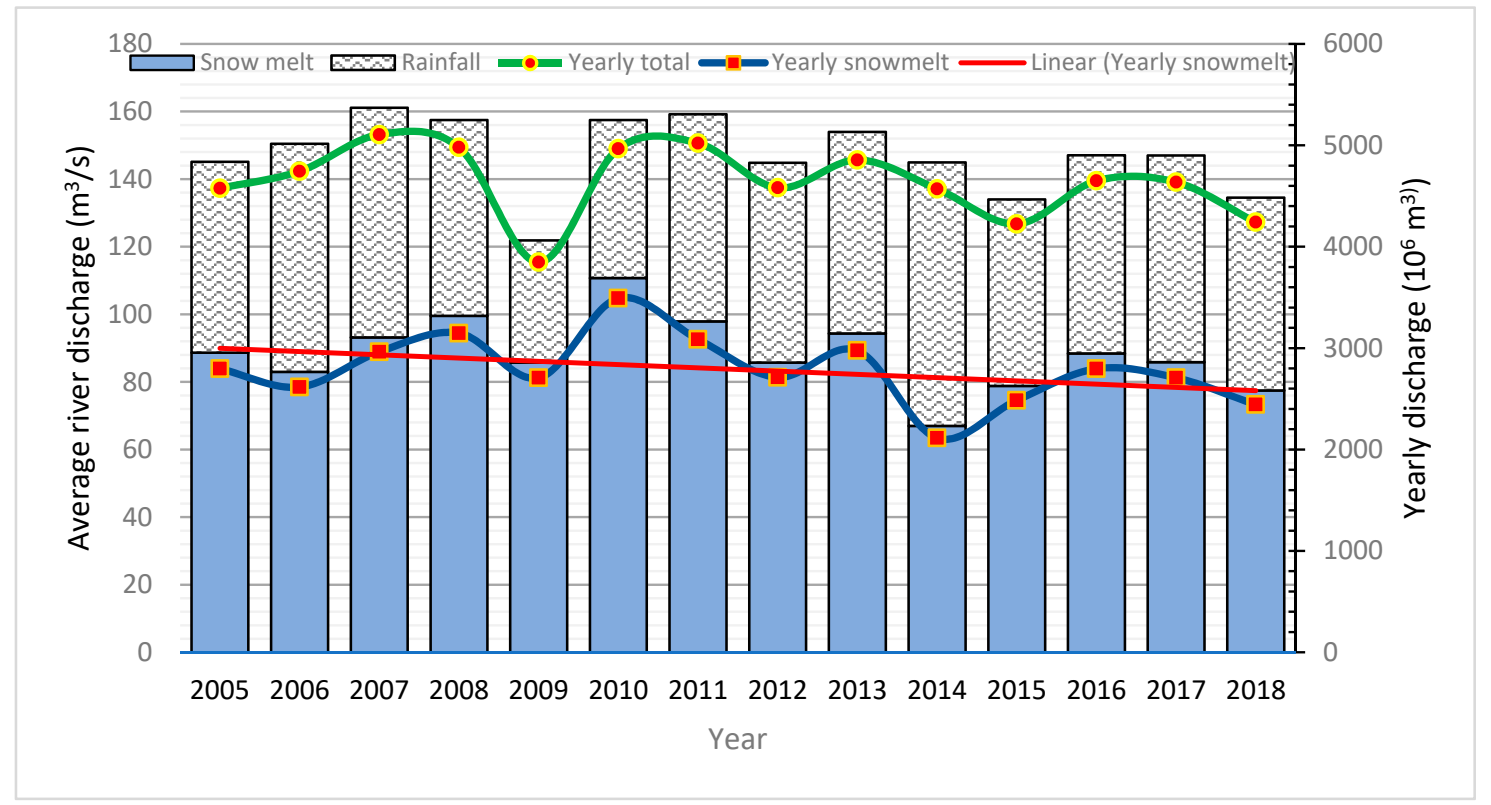

Figure 10. Snowmelt contribution in Budhi Gandaki River discharge.

\subsection{SRM Application}

SRM helps to understand discharge variation at the basin scale. Therefore, studies have used hydrological models as a predictive tool for climate extreme such as floods and drought and their socioeconomic costs [61]. Reduced snowmelt contribution to river discharge will create agriculture drought; on the other hand, excess river discharge triggers downstream flooding [1]. Many studied have applied SRM with a variety of data sources, whereas very few studies have used SRM in Himalayan basins [17], which are the major headwater source of the Ganges River. Varieties of data sources have been used as input to run the model with partial help of station-based measured data $[17,19,62,63]$. However, there are many small and medium-sized river basins in the Himalayan region without meteorological stations. In such conditions, the verification of meteorological satellite data products for the SRM model is very important; hence, this study verifies the application of ECMWF temperature and precipitation data products to run SRM in the Himalayan region.

SRM has been used in snowmelt-associated streamflow forecasting and for assessing the impact of climate change on snowmelt, particularly in the mountain watersheds where station-based meteorological data is scarce [64]. Verification of SRM for the particular basin was felt to be essential for measuring snowmelt accurately and observing the climate change impact on snowmelt $[17,29,62]$. Therefore, this study validates the SRM model in the Gandaki River Basin with high accuracy. Xiang et al. [23] concluded that SRM gives good results in a multi-year calibration, whereas this study uses SRM for yearly calibration, and it performs well in the BGRB. River discharge modelling helps to identify possible future events, i.e., drought or flood, under the climate change scenario [65]. Although the SRM model result responded well with measured discharge, the model is unable to grasp the extreme peak of the discharge; this means that the model cannot be used to detect riverine flooding.

Since many meteorological forecasts are major limitations for hydrological modelling, remote sensing data provides a reliable means for hydrological modelling and snowmelt runoff forecasting, which are vital for water resource management [66]. The SRM forecasts revealed good agreement with the measurements, confirming satellite data usefulness; Nagler et al. [66] came to similar conclusions. 
One study concluded that the onset of snowmelt runoff is likely to shift earlier and snowmelt discharge will increase [23], which pose a challenge in freshwater management and disaster mitigation.

Many studies have used MODIS data to run the SRM model [10,17,66,67]; hence, this study used MOD10A2 data in the Himalayan region. Pandey et al. [17] identified the meteorological data limitations in their study because they have access station-based precipitation measurements, which is scarce in the Himalayan region and does not represent the whole basin [17]. To address data discontinuity, we used remote sensing data in this study, which increased the accuracy of the results. The ECMWF climatic datasets are widely used datasets $[28,44]$, whereas no studies have used these data in SRM applications. The result shows that SRM can be applied along with ECMWF meteorological data in any inaccessible sub-basin of GRB.

This result shows annual total snowmelt contribution is 60 percent in the study area throughout the study period (2005-2018). One study states that eastern Himalayan catchments received about 20 percent of total annual discharge from snowmelt [68]. A similar study in Sutluj basin of the western Himalayan region estimated that snowmelt contributes about $59 \%$ of the total annual discharge [56]. Likewise, the study shows that snowmelt contributes $34 \%$ of the total annual discharge in the Dudh Koshi River Basin $\left(3713 \mathrm{~km}^{2}\right)$ in eastern Nepal [15]. One study showed that the monthly mean of the Budhi Gandaki River has increased by 0.50, whereas river flow has decreased during the dry season (November to April) by 0.16 [30], which poses a risk of flood during the wet season and drought in the dry season.

\subsection{Climate Change and River Discharge}

The SRM result shows that snowmelt contribution is high during winter and pre-monsoon, and a similar conclusion was made by Gautam and Acharya (2012) in the Himalayan region [69]. A study has found that climate change has directly impacted river hydrology and concluded that the river flow of the GRB is decreasing [30]. They also found that the river flow is decreasing especially in the dry season [30], which will create water scarcity and dominant monsoon precipitation, with high snowmelt during summer season triggering downstream flooding. Snowmelt contribution to river discharge increases continuously when the summer season progresses (June and July), which is the time of monsoon rain in the HKH region [70].

One study has claimed that temperature and summer precipitation both have a negative relationship with snow cover [9]. This study snows high snowmelt at the beginning of the monsoon season, as found in the Hindukush Himalayan region [70]. Hayat et al. [1] concluded that snowmelt starts earlier in the lower elevations due to climate change-induced temperature rise, which may increase the frequency and intensity of flood in future [1]. Therefore, flood mapping in flood-prone areas needs to be delineated, which will be beneficial to prevent future flooding and improve water resource management [1,71]. However, parameter uncertainty is a significant challenge in hydrological climate change assessment in data-scarce regions [23].

Since climate change affects snow cover and rainfall patterns, it also alters the river discharge and downstream populations [72]. Many studies have concluded that the glacier and snow cover area is decreasing due to high melt as a result of temperature rise [1,15]. To understand snow and rain contribution to river discharge, SRM consists of a no-snow mode that disregards the snow depletion information and modifies the run only for year-round forecast and simulation [18].

\section{Conclusions}

This study used the SRM model in the BGRB and computes snowmelt contribution to overall river discharge from 2005 to 2018. Based on the station recorded daily discharge data, SRM parameters are optimized in the simulation mode for the years 2005 and 2006, and the parameters are finalized for the basin. In addition, the model was used to measure river discharge using satellite input variables for the years 2007-2012. The validation result shows high accuracy between measured and SRM calculated 
discharge. Based on the optimized parameter the model was used to calculate river discharge from the watershed for the years 2013-2018.

The result show that MODIS snow cover data and ECMWF meteorological data are very beneficial to run the SRM model in the data scarce Himalayan region. The model has excellent capability to evaluate snowmelt contribution to overall discharge, and easy access to various satellite imagery has contributed to the SRM efficiency. The SRM efficiency in high mountain catchments can be attributed to MODIS and ECMWF remote sensing data as an input variable for the model. Though the majority of melting occurs in summer and autumn, the streamflow for these periods was dominated by heavy monsoon rainfall. The study result provides an important guideline for water resource managers to develope an appropriate strategy for water resources management and hydropower development. Moreover, it also helps in proper freshwater planning, the efficient use of winter water flow, and in mitigation and preventive measures for the flood disaster.

Author Contributions: Conceptualization, T.P.P.S. and J.Z.; Formal analysis, T.P.P.S. and F.A.P.; Funding acquisition, J.Z.; Methodology, T.P.P.S. and N.N.; Project administration, J.Z. and L.S.; Supervision, J.Z. and N.R.K.; Validation, T.P.P.S., N.R.K. and B.P.; Writing—original draft, T.P.P.S.; Writing—review and editing, T.P.P.S., J.Z., F.A.P., B.P., L.S., and N.N. All authors have read and agreed to the published version of the manuscript.

Funding: This work was jointly supported by the CAS Strategic Priority Research Program (No. XDA19030402), the Natural Science Foundation of China (No. 41871253), and the Taishan Scholar Project of Shandong Province (No. TSXZ201712).

Acknowledgments: The first author would like to acknowledge the Chinese Academy of Sciences (CAS) and the World Academy of Sciences (TWAS) for awarding the CAS-TWAS President Fellowship to accomplish PhD degree. Further, we are thankful to Bipin Kumar Acharya from Sun Yat-Sen University, and Madan Krishna Suwal from Canada for their valuable comments and suggestions during the research. Besides that, we express sincere gratitude to Upama Ashish Koju from Kathmandu for collecting station data from the department of hydrology and meteorology, Government of Nepal. Last but not least, we would like to thank editors and anonymous reviewers for their valuable time and suggestions.

Conflicts of Interest: The authors declare no conflict of interests.

\section{References}

1. Hayat, H.; Akbar, T.A.; Tahir, A.A.; Hassan, Q.K.; Dewan, A.; Irshad, M. Simulating Current and Future River-Flows in the Karakoram and Himalayan Regions of Pakistan Using Snowmelt-Runoff Model and RCP Scenarios. Water 2019, 11, 761. [CrossRef]

2. Van Vliet, M.T.H.; Franssen, W.H.P.; Yearsley, J.R.; Ludwig, F.; Haddeland, I.; Lettenmaier, D.P.; Kabat, P. Global river discharge and water temperature under climate change. Glob. Environ. Chang. 2013, 23, 450-464. [CrossRef]

3. Viviroli, D.; Dürr, H.H.; Messerli, B.; Meybeck, M.; Weingartner, R. Mountains of the world, water towers for humanity: Typology, mapping, and global significance. Water Resour. Res. 2007. [CrossRef]

4. Singh, P.; Haritashya, U.K.; Kumar, N.; Singh, Y. Hydrological characteristics of the Gangotri Glacier, central Himalayas, India. J. Hydrol. 2006. [CrossRef]

5. IPCC. Summary for Policymakers. In Global Warming of $1.5^{\circ} \mathrm{C}$; An IPCC Special Reports on Impacts of Global Warming of $1.5^{\circ} \mathrm{C}$ above Pre Industrial Levels and Related Global Greenhouse Gas Emission Pathways in Context of Strengthening the Globel Response to the Threat of Climate Change, Sustainable Development, and Efforts to Eradicate Poverty; Masson-Delmotte, V., Zhai, P., Pörtner, H.-O., Roberts, D., Skea, J., Shukla, P.R., Pirani, A., Moufouma-Okia, W., Péan, C., Pidcock, R., Eds.; Intergovernmental Panel on Climate Change: Geneva, Switzerland, 2018.

6. Lu, Y.; Nakicenovic, N.; Visbeck, M.; Stevance, A.-S. Policy: Five priorities for the UN sustainable development goals. Nature 2015, 520, 432-433. [CrossRef]

7. UNEP. Global Glacier Changes: Facts and Figures; United Nations Environment Programme/WGMS: Geneva, Switzerland, 2008.

8. Rabatel, A.; Francou, B.; Soruco, A.; Gomez, J.; Cáceres, B.; Ceballos, J.L.; Basantes, R.; Vuille, M.; Sicart, J.E.; Huggel, C.; et al. Current state of glaciers in the tropical Andes: A multi-century perspective on glacier evolution and climate change. Cryosphere 2013. [CrossRef] 
9. Khadka, D.; Babel, M.S.; Shrestha, S.; Tripathi, N.K. Climate change impact on glacier and snow melt and runoff in Tamakoshi basin in the Hindu Kush Himalayan (HKH) region. J. Hydrol. 2014. [CrossRef]

10. Tahir, A.A.; Chevallier, P.; Arnaud, Y.; Neppel, L.; Ahmad, B. Modeling snowmelt-runoff under climate scenarios in the Hunza River basin, Karakoram Range, Northern Pakistan. J. Hydrol. 2011. [CrossRef]

11. Siderius, C.; Biemans, H.; Wiltshire, A.; Rao, S.; Franssen, W.H.P.; Kumar, P.; Gosain, A.K.; van Vliet, M.T.H.; Collins, D.N. Snowmelt contributions to discharge of the Ganges. Sci. Total Environ. 2013, 468-469, S93-S101. [CrossRef]

12. Bolch, T.; Pieczonka, T.; Benn, D.I. Multi-decadal mass loss of glaciers in the Everest area (Nepal Himalaya) derived from stereo imagery. Cryosphere 2011. [CrossRef]

13. Mankin, J.S.; Viviroli, D.; Singh, D.; Hoekstra, A.Y.; Diffenbaugh, N.S. The potential for snow to supply human water demand in the present and future. Environ. Res. Lett. 2015, 10, 114016. [CrossRef]

14. Barnett, T.P.; Adam, J.C.; Lettenmaier, D.P. Potential impacts of a warming climate on water availability in snow-dominated regions. Nature 2005, 438, 303-309. [CrossRef] [PubMed]

15. Nepal, S.; Krause, P.; Flügel, W.A.; Fink, M.; Fischer, C. Understanding the hydrological system dynamics of a glaciated alpine catchment in the Himalayan region using the J2000 hydrological model. Hydrol. Process. 2014. [CrossRef]

16. Acharya, T.D.L.; Lee, D.H. Remote Sensing and Geospatial Technologies for Sustainable Development: A Review of Applications. Sens. Mater. 2019, 31, 3931-3945. [CrossRef]

17. Panday, P.K.; Williams, C.A.; Frey, K.E.; Brown, M.E. Application and evaluation of a snowmelt runoff model in the Tamor River basin, Eastern Himalaya using a Markov Chain Monte Carlo (MCMC) data assimilation approach. Hydrol. Process. 2014. [CrossRef]

18. Adnan, M.; Nabi, G.; Saleem Poomee, M.; Ashraf, A. Snowmelt runoff prediction under changing climate in the Himalayan cryosphere: A case of Gilgit River Basin. Geosci. Front. 2017. [CrossRef]

19. Boudhar, A.; Hanich, L.; Boulet, G.; Duchemin, B.; Berjamy, B.; Chehbouni, A. Evaluation of the Snowmelt Runoff model in the Moroccan High Atlas Mountains using two snow-cover estimates. Hydrol. Sci. J. 2009. [CrossRef]

20. Rango, A.; Martinec, J.; Roberts, R. Relative Importance of glacier contribution to water supply in a changing climate. World Resour. Rev. 2008, 3, 487-503.

21. Tekeli, A.E.; Akyürek, Z.; Şorman, A.A.; Şensoy, A.; Şorman, A.Ü. Using MODIS snow cover maps in modeling snowmelt runoff process in the eastern part of Turkey. Remote Sens. Environ. 2005. [CrossRef]

22. Elias, E.H.; Rango, A.; Steele, C.M.; Mejia, J.F.; Smith, R. Assessing climate change impacts on water availability of snowmelt-dominated basins of the Upper Rio Grande basin. J. Hydrol. Reg. Stud. 2015. [CrossRef]

23. Xiang, Y.; Li, L.; Chen, J.; Xu, C.-Y.; Xia, J.; Chen, H.; Liu, J. Parameter Uncertainty of a Snowmelt Runoff Model and Its Impact on Future Projections of Snowmelt Runoff in a Data-Scarce Deglaciating River Basin. Water 2019, 11, 2417. [CrossRef]

24. Immerzeel, W.W.; Lutz, A.F.; Andrade, M.; Bahl, A.; Biemans, H.; Bolch, T.; Hyde, S.; Brumby, S.; Davies, B.J.; Elmore, A.C.; et al. Importance and vulnerability of the world's water towers. Nature 2020, 577, 364-369. [CrossRef] [PubMed]

25. Kustas, W.P.; Rango, A.; Uijlenhoet, R. A simple energy budget algorithm for the snowmelt runoff model. Water Resour. Res. 1994. [CrossRef]

26. Jain, S.K.; Goswami, A.; Saraf, A.K. Snowmelt runoff modelling in a Himalayan basin with the aid of saellite data. Int. J. Remote Sens. 2010, 31, 6603-6618. [CrossRef]

27. Bookhagen, B.; Burbank, D.W. Topography, relief, and TRMM-derived rainfall variations along the Himalaya. Geophys. Res. Lett. 2006, 33. [CrossRef]

28. Haile, A.T.; Tefera, F.T.; Rientjes, T. Flood forecasting in Niger-Benue basin using satellite and quantitative precipitation forecast data. Int. J. Appl. Earth Obs. Geoinf. 2016, 52, 475-484. [CrossRef]

29. Immerzeel, W.W.; Ludovicus, P.H.v.B.; Marc, F.P.B. Climate Change Will Affect the Asian Water Towers. Science 2010, 328, 1382-1385. [CrossRef]

30. Bajracharye, T.R.; Acharya, S.; Ale, B.B. Changing Climatic Parameter and its Possible Impacts in Hydropower Generation in Nepal: A Case Study on Gandaki River Bain. J. Inst. Eng. 2011, 8, 160-173. [CrossRef]

31. Shrestha, A.B.; Joshi, S.P. Snow Cover and Glacier Change Study in Nepalese Himalaya Using Remote Sensing and Geographic Information System. J. Hydrol. Meteorol. 2011, 6, 26-36. [CrossRef] 
32. Bajracharya, S.R.; Mool, P.K.; Shrestha, B.R. Impact of Climate Change on Himalayan Glaciers and Glacial Lakes: Case Studies on GLOF and Associated Hazards in Nepal and Bhutan; International Centre for Integrated Mountain Development (ICIMOD): Lalitpur, Nepal, 2007.

33. IPCC. Summary for Policymakers. In Climate Change 2013-The Physical Science Basis: Working Group I Contribution to the Fifth Assessment Report of the Intergovernmental Panel on Climate Change; Cambridge University Press: Cambridge, UK, 2014; pp. 1-30. [CrossRef]

34. Paudel, B.; Zhang, Y.; Yan, J.; Rai, R.; Li, L.; Wu, X.; Chapagain, P.S.; Khanal, N.R. Farmers' understanding of climate change in Nepal Himalayas: Important determinants and implications for developing adaptation strategies. Clim. Chang. 2020, 158, 485-502. [CrossRef]

35. Betts, A.K.; Jakob, C. Evaluation of the diurnal cycle of precipitation, surface thermodynamics, and surface fluxes in the ECMWF model using LBA data. J. Geophys. Res. Atmos. 2002, 107, LBA-12. [CrossRef]

36. Karki, R.; Talchabhadel, R.; Aalto, J.; Baidya, S.K. New climatic classification of Nepal. Theor. Appl. Climatol. 2016, 125, 799-808. [CrossRef]

37. NASA. MODIS Web; National Aeronautics and Space Administration: Washington, DC, USA, 2014.

38. Hall, D.K.; Riggs, G.A.; Salomonson, V.V.; DiGirolamo, N.E.; Bayr, K.J. MODIS snow-cover products. Remote Sens. Environ. 2002. [CrossRef]

39. Riggs, G.; Hall, D. MODIS Snow Products User Guide to Collection 6; National Snow and Ice Data Center (NSIDC): Boulder, CO, USA, 2015.

40. Vermote, J.C.; Ray, J.P. MODIS Surface Reflectance User's Guide Collection 6; MODIS Land Surface Reflectance Science Computing Facility: Greenbelt, MD, USA, 2015.

41. Gobiet, A.; Foelsche, U.; Steiner, A.K.; Borsche, M.; Kirchengast, G.; Wickert, J. Climatological validation of stratospheric temperatures in ECMWF operational analyses with CHAMP radio occultation data. Geophys. Res. Lett. 2005, 32. [CrossRef]

42. Wang, X.; Song, L.; Cao, Y. Analysis of the weighted mean temperature of china based on sounding and ECMWF reanalysis data. Acta Meteorol. Sin. 2012, 26, 642-652. [CrossRef]

43. Poli, P.; Healy, S.B.; Dee, D.P. Assimilation of Global Positioning System radio occultation data in the ECMWF ERA-Interim reanalysis. Q. J. R. Meteorol. Soc. 2010, 136, 1972-1990. [CrossRef]

44. Koju, U.A.; Zhang, J.; Maharjan, S.; Bai, Y.; Zhang, S.; Yao, F. Analysis of spatiotemporal dynamics of forest Net Primary Productivity of Nepal during 2000-2015. Int. J. Remote Sens. 2020. [CrossRef]

45. Farr, T.G.; Rosen, P.A.; Caro, E.; Crippen, R.; Duren, R.; Hensley, S.; Kobrick, M.; Paller, M.; Rodriguez, E.; Roth, L.; et al. The shuttle radar topography mission. Rev. Geophys. 2007. [CrossRef]

46. Sun, G.; Ranson, K.J.; Kharuk, V.I.; Kovacs, K. Validation of surface height from shuttle radar topography mission using shuttle laser altimeter. Remote Sens. Environ. 2003. [CrossRef]

47. Schumann, G.; Matgen, P.; Cutler, M.E.J.; Black, A.; Hoffmann, L.; Pfister, L. Comparison of remotely sensed water stages from LiDAR, topographic contours and SRTM. ISPRS J. Photogramm. Remote Sens. 2008, 63, 283-296. [CrossRef]

48. Yang, L.; Meng, X.; Zhang, X. SRTM DEM and its application advances. Int. J. Remote Sens. 2011, 32, 3875-3896. [CrossRef]

49. Martinec, J. Snowmelt-runoff model for stream flow forecasts. Nord. Hydrol. 1975, 6, 145-154. [CrossRef]

50. Martinec, J.; Rango, A.; Major, E. The Snowmelt Runoff Model (SRM) User's Manual; NASA: Washington, DC, USA, 1983.

51. Martinec, J.; Rango, A. Parammeter Values for Snowmelt Runoff Modelling. J. Hydrol. 1986, 84, 197-219. [CrossRef]

52. Martinec, J.; Rango, A.; Robert, R.T. Snowmelt Runoff Model (SRM) User's Manual; New Maxico State University Press: Las Cruces, NM, USA, 2008.

53. Singh, S.K.; Rathore, B.P.; Bahuguna, I.M.; Ajai. Snow cover variability in the Himalayan-Tibetan region. Int. J. Climatol. 2014. [CrossRef]

54. Kattel, D.B.; Yao, T.; Yang, K.; Tian, L.; Yang, G.; Joswiak, D. Temperature lapse rate in complex mountain terrain on the southern slope of the central Himalayas. Theor. Appl. Climatol. 2013, 113, 671-682. [CrossRef]

55. Zhang, S.; Ye, B.; Liu, S.; Zhang, X.; Hagemann, S. A modified monthly degree-day model for evaluating glacier runoff changes in China. Part I: Model development. Hydrol. Process. 2012, 26, 1686-1696. [CrossRef]

56. Singh, P.; Jain, S.K. Modelling of streamflow and its components for a large Himalayan basin with predominant snowmelt yields. Hydrol. Sci. J. 2003. [CrossRef] 
57. Jain, S.K.; Goswami, A.; Saraf, A.K. Accuracy assessment of MODIS, NOAA and IRS data in snow cover mapping under Himalayan conditions. Int. J. Remote Sens. 2008, 29, 5863-5878. [CrossRef]

58. Kulkarni, A.V.; Rathore, B.P.; Singh, S.K. Distribution of seasonal snow cover in central and western Himalaya. Ann. Glaciol. 2010, 51, 123-128. [CrossRef]

59. Ferris, J.S.; Congalton, R.G. Satellite and Geographic Information System Estimates of Colorado River Basin Snowpack; University of California: Berkeley, CA, USA, 1989.

60. Mark, B.G.; Baraer, M.; Fernandez, A.; Immerzeel, W.; Moore, R.D.; Weingartner, R. Glaciers as water resources. In The High-Mountain Cryosphere: Environmental Changes and Human Risks; Huggel, C., Carey, M., Clague, J., Kääb, A., Eds.; Cambridge University Press: Cambridge, UK, 2015; pp. 184-203. [CrossRef]

61. Blöschl, G.; Kirnbauer, R. Point snowmelt models with different degrees of complexity-Internal processes. J. Hydrol. 1991. [CrossRef]

62. Tayal Senzeba, K.; Bhadra, A.; Bandyopadhyay, A. Snowmelt runoff modelling in data scarce Nuranang catchment of eastern Himalayan region. Remote Sens. Appl. Soc. Environ. 2015. [CrossRef]

63. Steele, C.; Dialesandro, J.; James, D.; Elias, E.; Rango, A.; Bleiweiss, M. Evaluating MODIS snow products for modelling snowmelt runoff: Case study of the Rio Grande headwaters. Int. J. Appl. Earth Obs. Geoinf. 2017. [CrossRef]

64. Abudu, S.; Cui, C.-1.; Saydi, M.; King, J.P. Application of snowmelt runoff model (SRM) in mountainous watersheds: A review. Water Sci. Eng. 2012. [CrossRef]

65. Dewan, T.H. Societal impacts and vulnerability to floods in Bangladesh and Nepal. Weather Clim. Extrem. 2015, 7, 36-42. [CrossRef]

66. Nagler, T.; Rott, H.; Malcher, P.; Müller, F. Assimilation of meteorological and remote sensing data for snowmelt runoff forecasting. Remote Sens. Environ. 2008. [CrossRef]

67. Sichangi, A.W.; Wang, L.; Yang, K.; Chen, D.; Wang, Z.; Li, X.; Zhou, J.; Liu, W.; Kuria, D. Estimating continental river basin discharges using multiple remote sensing data sets. Remote Sens. Environ. 2016, 179, 36-53. [CrossRef]

68. Bookhagen, B.; Burbank, D.W. Toward a complete Himalayan hydrological budget: Spatiotemporal distribution of snowmelt and rainfall and their impact on river discharge. J. Geophys. Res. Earth Surf. 2010, 115, 1-25. [CrossRef]

69. Gautam, M.R.; Acharya, K. Streamflow trends in Nepal. Hydrol. Sci. J. 2012, 57, 344-357. [CrossRef]

70. Tiwari, S.; Kar, S.C.; Bhatla, R. Snowfall and Snowmelt Variability over Himalayan Region in Inter-annual Timescale. Aquat. Procedia 2015, 4, 942-949. [CrossRef]

71. Rimal, B.; Sloan, S.; Keshtkar, H.; Sharma, R.; Rijal, S.; Shrestha, U.B. Patterns of Historical and Future Urban Expansion in Nepal. Remote Sens. 2020, 12, 628. [CrossRef]

72. De Silva, M.M.G.T.; Kawasaki, A. Socioeconomic Vulnerability to Disaster Risk: A Case Study of Flood and Drought Impact in a Rural Sri Lankan Community. Ecol. Econ. 2018, 152, 131-140. [CrossRef]

(C) 2020 by the authors. Licensee MDPI, Basel, Switzerland. This article is an open access article distributed under the terms and conditions of the Creative Commons Attribution (CC BY) license (http://creativecommons.org/licenses/by/4.0/). 